\title{
The Temporal Variation of Magma Plumbing System of the Kattadake Pyroclastics in the Zao Volcano, Northeastern Japan
}

\author{
Mirai Takebe ${ }^{1}$, Masao Ban ${ }^{1, *}$, Motohiro Sato ${ }^{2}$ and Yuki Nishi ${ }^{2}$ \\ 1 Department of Science, Faculty of Science, Yamagata University, Yamagata 990-8560, Japan; \\ s104_za_09koa@yahoo.co.jp \\ 2 Department of Interactive Symbiosphere Sciences, Graduate School of Science and Technology, \\ Yamagata University, Yamagata 990-8560, Japan; s201002d@st.yamagata-u.ac.jp (M.S.); \\ west.yuki.1124@gmail.com (Y.N.) \\ * Correspondence: ban@sci.kj.yamagata-u.ac.jp
}

\section{check for} updates

Citation: Takebe, M.; Ban, M.; Sato, M.; Nishi, Y. The Temporal Variation of Magma Plumbing System of the Kattadake Pyroclastics in the Zao Volcano, Northeastern Japan. Minerals 2021, 11, 430. https:// doi.org/10.3390/min11040430

Academic Editors:

Gabriele Lanzafame,

Federico Casetta, Pier

Paolo Giacomoni and Ivan Vlastélic

Received: 15 February 2021

Accepted: 15 April 2021

Published: 18 April 2021

Publisher's Note: MDPI stays neutral with regard to jurisdictional claims in published maps and institutional affiliations.

Copyright: (c) 2021 by the authors. Licensee MDPI, Basel, Switzerland. This article is an open access article distributed under the terms and conditions of the Creative Commons Attribution (CC BY) license (https:/ / creativecommons.org/licenses/by/ $4.0 /)$.

\begin{abstract}
The geologic and petrologic study of the Kattadake pyroclastics (around $10 \mathrm{ka}$ ) from the Zao volcano (NE Japan) revealed the structure of the magma plumbing system and the mixing behavior of the shallow chamber. The Kattadake pyroclastic succession is divided into lower and upper parts by a remarkable discontinuity. All rocks belong to medium-K, calc-alkaline rock series and correspond to ol-cpx-opx basaltic-andesite to andesite with 20-28 vol\% phenocrystic modal percentage. All rocks were formed by mixing between andesitic magma and near aphyric basalt. The petrologic features of andesites of lower and upper parts are similar, 59-61 wt\% $\mathrm{SiO}_{2}$, having lowAn plagioclase and low-Mg pyroxenes, with pre-eruptive conditions corresponding to $960-980{ }^{\circ} \mathrm{C}$, 1.9-3.5 kb, and 1.9-3.4 wt \% $\mathrm{H}_{2} \mathrm{O}$. However, the basalts were ca. $49.4 \mathrm{wt} \% \mathrm{SiO}_{2}$ with $\mathrm{Fo}_{\sim 84}$ olivine in the lower part and $51.8 \mathrm{wt} \% \mathrm{SiO}_{2}$ with $\mathrm{Fo}_{\sim 81}$ olivine and high-An plagioclase the in upper one. The percentage of basaltic magma in the mixing process was lower, but the temperature of the basalt was higher in the lower part than the upper one. This means that the shallow magma chamber was reactivated more efficiently by the hotter basalts and that the mixed magma with a $70-80 \%$ of melt fraction was formed by a smaller percentage of the basaltic magma.
\end{abstract}

Keywords: reactivation of shallow magma chamber; calc-alkaline mixed magma; injection of mafic magma; Zao volcano NE Japan

\section{Introduction}

Magma mixing is a common triggering mechanism in many arc volcanoes (Manrique 2019 [1]; Hodge and Jellinek 2020 [2]). In most cases, the intrusion of deeper and hotter magma into a shallow magma chamber is the cause of such a process, which may evolve from mingling to mixing depending on the time the two magmas are in contact before the eruption (Murphy et al. 2000 [3]; Plail et al. 2018 [4]). In some cases, the overpressure caused by the intrusion of the new magma into the magma chamber is sufficient to trigger the eruption (Izbekov et al. 2004 [5]; Patia et al. 2017 [6]), while in others, an additional contribution (e.g., exsolution of volatiles) is required to reach the eruption conditions (Eichelberger 1980 [7]; Synder 2000 [8]). This may require keeping the two magmas in contact a certain time, during which they may allow chemical diffusion and facilitate magma mixing (Cooper 2018 [9]; Nishi et al. 2019 [10]). The detailed petrologic examination of erupted mixed rock provides important information about the processes of the reactivation of the shallow chamber and mixing (Singer et al. 2016 [11]; Morgado et al. 2019 [12]).

Here, we report the petrologic and volcanologic features of the Kattadake pyroclastics (ca. $10 \mathrm{ka}$ ) from the youngest eruption stage of the Zao volcano in NE Japan. These pyroclastic rocks show typical characteristics of mixing products and exhibit contrasting petrologic features along the whole succession of deposits. These differences allow us to examine the reactivation behavior of the shallow chamber magma. We define the 
petrologic features of the end-member magmas involved in the mixing based on the chemical compositions of whole rock and phenocryst minerals as well as petrographic data, and we discuss how the reactivation processes of shallow chamber occurred.

\section{Geologic Setting}

Eighteen active volcanoes are distributed in NE Japan (Figure 1a). The Zao volcano is one of the active stratovolcanoes, located at the volcanic front (Figure 1a). Many volcanic tremors have been detected since 2013 (Yamamoto et al. 2014 [13]; Ban et al. 2019 [14]; Miura et al. 2018 [15]). The volcanic activity started at $\sim 1$ Ma. The activity is divided into six stages (Ban et al. 2015 [16]; Figure 1b), which show different volcanologic and petrologic features. The youngest (sixth) stage is characterized by explosive eruptions of basaltic andesite to andesitic magmas. At the beginning of this stage (ca. $35 \mathrm{ka}$ ), a horseshoe-shaped Umanose caldera ( $\sim 1.7 \mathrm{~km}$ in diameter) formed at the summit area. Ban et al. (2015) [16] subdivided the pyroclastic deposits of this stage into the Kumanodake pyroclastics (ca. 33-12.9 ka), Komakusadaira pyroclastics (ca. 33-12.9 ka), Kattadake pyroclastics (around $10 \mathrm{ka}$ ), Umanose agglutinate (ca. 9.0-4.1 ka), and Goshikidake pyroclastics (ca. 2.0 ka to present).
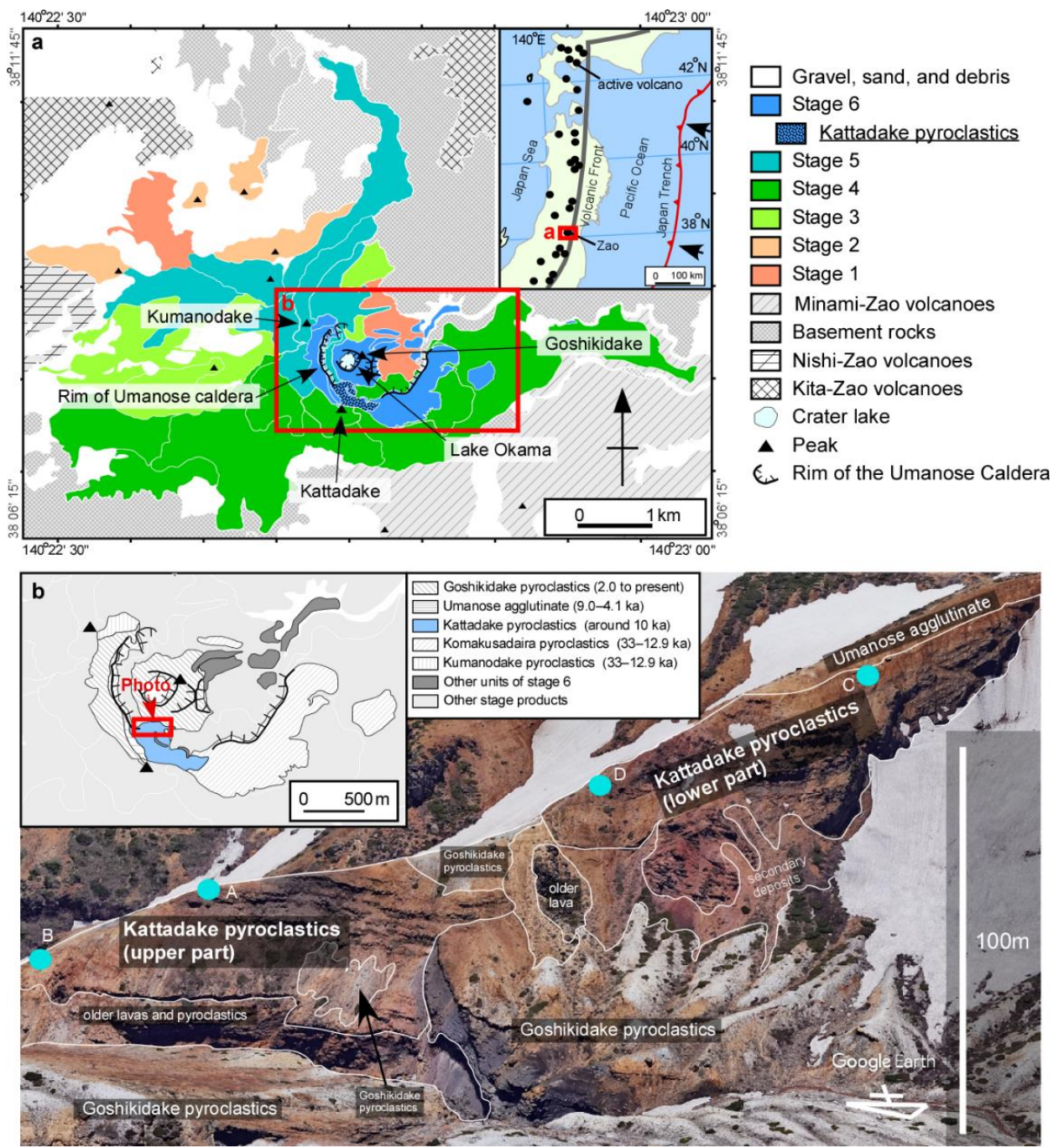

Figure 1. (a) The geological sketch map of Zao volcano from Ban et al. (2015) [16], (b) closed up of the summit area, and a view photo of the Kattadake pyroclastics. The inset in (a) shows distribution of active volcanoes in NE Japan and the surrounding areas. A, B, C, and D are equivalent to the labels in Figure 2. 

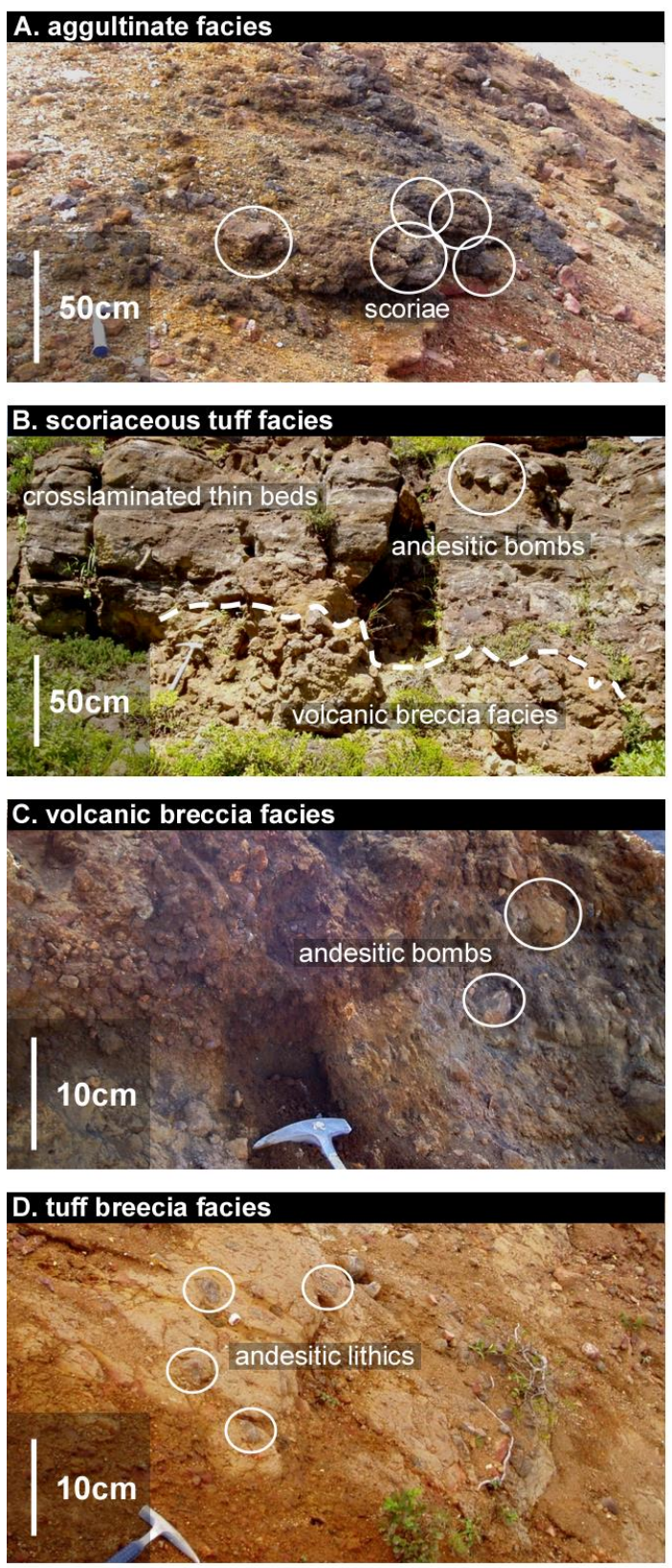

secondary deposits

Q scoriaceous tuff

口

agglutinate (alteration)

tuff breccia

200 volcanic breccia

응 volcanic breccia (alteration)

圈 older lava

$O$ andesitic bomb

$\Delta$ scoria fragments

- scoria fragments (alteration)

sampling layers

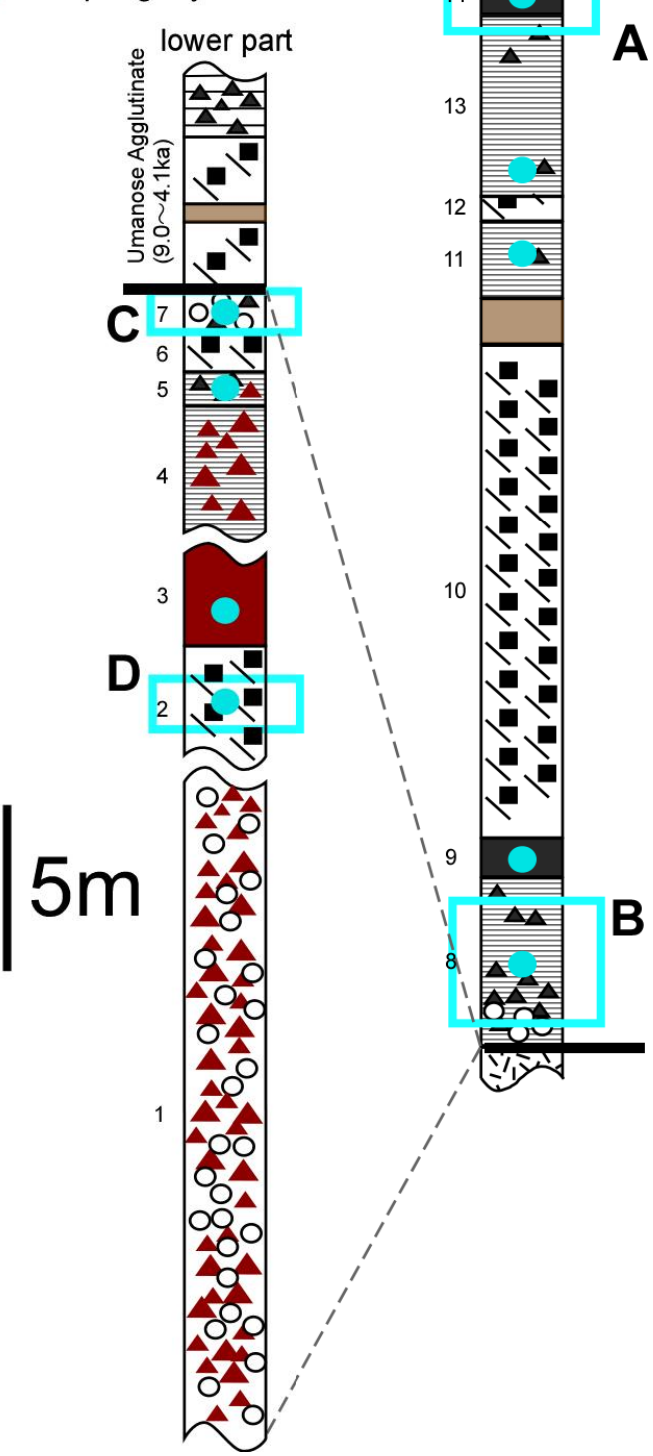

Figure 2. Photographs of representative facies and the columnar sections of the Kattadake pyroclastics. (A) Agglutinate facies, (B) scoriaceous tuff facies, showing planar stratification, (C) volcanic breccia facies, and (D) tuff breccia facies (having white to yellow clay matrix). The hammer in the photographs is $32 \mathrm{~cm}$ in length. Samples were collected from layers 2, 3, 5, $7,8,9,11,13,14,15,16,17$, and 18. A, B, C, and D are equivalent to the labels in Figure 1.

The Kattadake pyroclastics are distributed in the western part of the Umanose caldera (Figure 1b). The deposits are well exposed in the north part of the study area (Figure 1b). The Kattadake pyroclastic succession can be divided into lower and upper parts. The latter 
mainly locates east of the former and abuts on the former. We recognized 18 pyroclastic beds based on facies changes or intercalation of the secondary deposits (Figure 2). The beds range in thickness from ca. $50 \mathrm{~cm}$ to $20 \mathrm{~m}$.

Deposits of the Kattadake pyroclastic succession show the following four facies: agglutinate, scoriaceous tuff, volcanic breccia, and tuff breccia. The agglutinate facies (Figure 2a) consists of mainly coarse scoria fragments (including spatter) with minor amounts of finer ones in a ash matrix. The scoriaceous tuff facies (Figure $2 b$ ) consists of weak planar and cross laminated thin beds, up to $30 \mathrm{~cm}$ in thickness, composed of black to dark gray scoriaceous ashes and crystal fragments. Subordinate amounts of gray and angular andesitic bombs or black to dark gray scoria fragments, which usually show a rounded shape, are observed. The volcanic breccia facies (Figure $2 c$ ) are poorly sorted, clastsupported, and characterized by abundant lithic fragments and andesitic bombs in a matrix of reddish-brown ash. The bombs often show a quenched texture. The lithic fragments and bombs of this facies in the lower part tend to show brownish-red color (photographs in Figure 2). The tuff breccia (Figure 2d) facies can be subdivided into following two. One is similar to the volcanic breccia facies, but has less amounts of lithic fragments and bombs. The other is characterized by abundant lithic fragments in a white to yellow clay matrix. The scoriaceous tuff and tuff breccia facies are dominant and the other two facies are subordinately observed (columnar section of Figure 2).

\section{Materials and Methods}

We collected 30 juvenile fragments (9 from the lower part and 21 from the upper part) of the Kattadake pyroclastics. We did not collect samples from the lower layers of the lower part, where many of the rocks were reddish colored due to oxidation.

Modal analyses were performed on thin sections by point counting (2000 counts) using a petrographic microscope or on photographic images of the thin sections by a graphical method using ImageJ software.

Whole-rock major element and trace element ( $\mathrm{Rb}, \mathrm{Sr}, \mathrm{Ba}, \mathrm{Zr}, \mathrm{Y}, \mathrm{Nb}, \mathrm{V}, \mathrm{Cr}$, and $\mathrm{Ni}$ ) concentrations were determined by X-ray fluorescence (XRF) analysis with a Rigaku RIX2000 analyzer (Rigaku, Tokyo, Japan) at Yamagata University. The operating conditions included an acceleration voltage of $50 \mathrm{kV}$ and a current of $50 \mathrm{~mA}$. The preparation method of the glass discs and the calibration method used for major and trace elements followed those of Yamada et al. (1995) [17]. The glass discs were made by fusion of powdered sample with Lithium tetraborate. The matrix effect for trace elements was corrected by using the $\mathrm{Ip} / \mathrm{Ib}$ (net over background intensity) method. For a detailed explanation of this method, see Murata (1993) [18] and Yamada et al. (1995) [17]. The standards used in this analysis are the Geological Survey of Japan (GSJ) igneous rock series. The analytical uncertainties of the XRF trace elements analyses are $<5 \%$ for $\mathrm{Nb}, \mathrm{Zr}, \mathrm{Y}, \mathrm{Sr}, \mathrm{Rb}$, and $\mathrm{Ni} ;<10 \%$ for $\mathrm{V}$ and $\mathrm{Cr}$; and $5-15 \%$ for Ba. The range of uncertainties for a single element is based on the concentration range observed in the standards. Major elements have been normalized to a $100 \%$ volatile-free basis, with total iron $\left(\mathrm{FeO}^{t}\right)$ calculated as $\mathrm{FeO}$ for plotting purposes.

The mineral compositions (plagioclase, pyroxene, and olivine) of 5 samples were analyzed using a JEOL JXA8600M (Jeol Ltd., Tokyo, Japan) wavelength-dispersive type electron probe X-ray microanalyzer (EPMA) at Yamagata University. These analyses operated with an acceleration voltage of $15 \mathrm{kV}$, a beam current of $10 \mathrm{nA}$ (plagioclase) or a $20 \mathrm{nA}$ (pyroxene and olivine) and beam diameter of $1 \mu \mathrm{m}$ (pyroxene and olivine) or $5 \mu \mathrm{m}$ (plagioclase). All analyses used oxide ZAF (atomic number, absorption, and fluorescence) corrections.

\section{Results}

\subsection{Modal and Whole Rock Compositions}

The modal compositions of lower and upper parts of the Kattadake pyroclastic succession are shown in Table 1. Rocks have porphyritic index values ranging $19.9-28.4 \mathrm{vol} \%$, with phenocrysts of plagioclase (12.1-22.6 vol\%), orthopyroxene (3.7-5.9 vol\%), clinopyroxene 
(0.7-2.9 vol\%), olivine (0-3.4 vol\%), and rare magnetite, set in an intersertal groundmass. The photomicroscope images of representative samples are presented in Figure 3. Glomerocrystals of phenocrysts of plagioclase and olivine are sometimes observed in samples from the lower part.

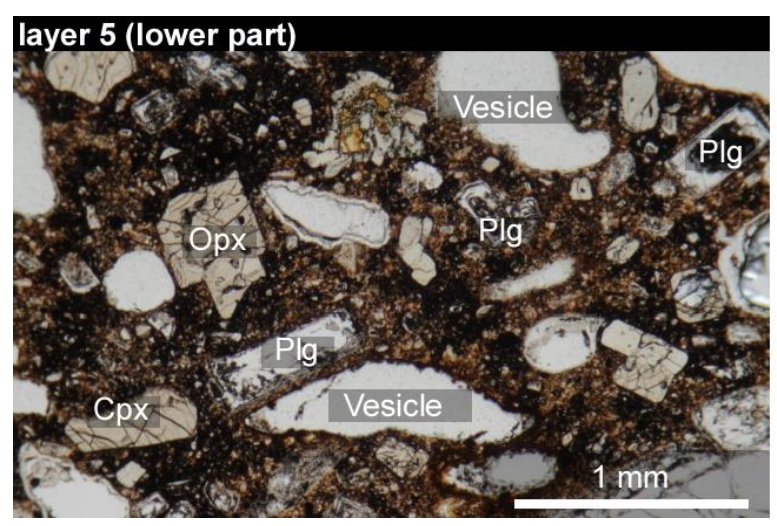

(a)

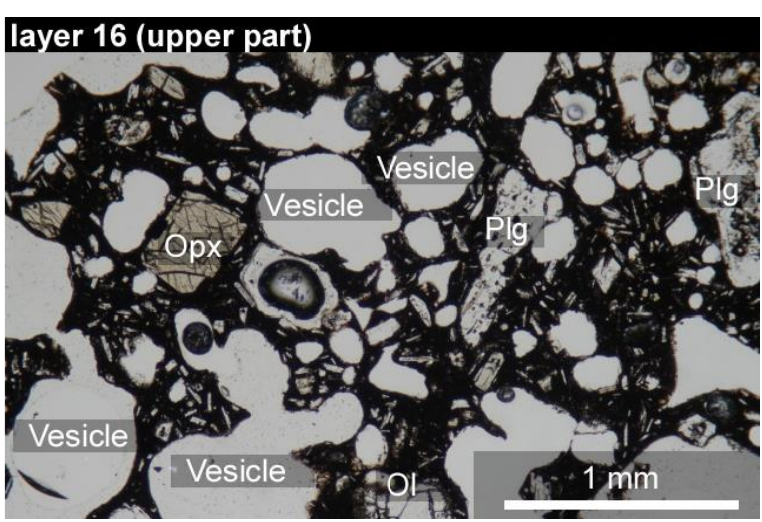

(b)

Figure 3. Photomicroscope images of representative samples from Kattadake pyroclastics. Ol, olivine; Opx, orthopyroxene; Cpx, clinopyroxene. (a) representative samples from the lower part, (b) representative samples from the upper part.

All whole-rock compositions of Kattadake pyroclastics are presented in Table 2. The major and trace element variation diagrams are shown in Figure 4a. The Kattadake pyroclastics belong to the medium-K calc-alkaline series according to the classification scheme by Gill (1981) [19] and Miyashiro (1974) [20] (Figure 4). $\mathrm{SiO}_{2}$ contents of the Kattadake pyroclastics are 55.0-58.4 $\mathrm{wt} \%$. In the $\mathrm{SiO}_{2}$ variation diagrams, the whole rock data show linear trends, except for $\mathrm{Cr}, \mathrm{Ni}$, and $\mathrm{MgO}$. In the $\mathrm{Cr}, \mathrm{Ni}$, and $\mathrm{MgO}$ diagrams, rocks from the lower part show a $\mathrm{Cr}, \mathrm{Ni}$, and $\mathrm{MgO}$-rich trend (high-Cr group), whereas the upper rocks show a $\mathrm{Cr}, \mathrm{Ni}$, and $\mathrm{MgO}$-poor trend (low-Cr group).

Figure $4 \mathrm{~b}$ shows the temporal variation of $\mathrm{SiO}_{2}, \mathrm{MgO}, \mathrm{K}_{2} \mathrm{O}$, and analyzed trace element contents. In this figure, $\mathrm{SiO}_{2}, \mathrm{~K}_{2} \mathrm{O}, \mathrm{Ba}, \mathrm{Rb}, \mathrm{Y}, \mathrm{Zr}, \mathrm{Nb}, \mathrm{Cr}$, and $\mathrm{Ni}$ contents of the lower part tend to be richer than the upper part. The variations in $\mathrm{MgO}, \mathrm{V}$, and $\mathrm{Sr}$ contents do not show clear temporal variation. 
Table 1. Phenocryst modal composition of lower and upper parts of the Kattadake pyroclastics.

\begin{tabular}{|c|c|c|c|c|c|c|c|c|c|c|c|c|c|}
\hline \multirow{2}{*}{$\begin{array}{c}\text { Part } \\
\text { Sample Name }\end{array}$} & \multicolumn{7}{|c|}{ Lower } & \multicolumn{6}{|c|}{ Upper } \\
\hline & $051027-501$ & 050916-301* & 050916-401 & 06KTS10-2 * & TZ2 & $\mathrm{Z2}-31$ * & $\mathrm{Z} 2-32 *$ & SS32* & $051027-3$ * & SC-1 & $051027-4$ * & 0510278-2 & SF-201* \\
\hline Total phenocryst (vol\%) & 27.9 & 26.1 & 24.8 & 22.8 & 19.9 & 22.9 & 28.3 & 28.4 & 26.3 & 20.5 & 24.6 & 26.7 & 26.9 \\
\hline Plagioclase (vol\%) & 21.6 & 16.4 & 17.1 & 17 & 12.1 & 15.8 & 18.1 & 18.6 & 22.6 & 13.4 & 16.8 & 14.5 & 20.0 \\
\hline $\begin{array}{c}\text { Orthopyroxene }+ \\
\text { clinopyroxene (vol\%) }\end{array}$ & 5.8 & 9.8 & 7.0 & 5.9 & 4.4 & 7.1 & 10.3 & 9.8 & 3.7 & 7.0 & 7.2 & 7.8 & 6.9 \\
\hline Orthopyroxene (vol\%) & 4.1 & - & 5.9 & - & 3.7 & - & - & - & - & 5.2 & - & 4.9 & - \\
\hline Clinopyroxene (vol\%) & 1.7 & - & 1.1 & - & 0.7 & - & - & - & - & 1.8 & - & 2.9 & - \\
\hline Olivine (vol\%) & 0.5 & 0.0 & 0.6 & trace & 3.4 & trace & trace & 0.0 & 0.0 & 0.0 & 0.0 & 1.8 & 0.0 \\
\hline Fe-Ti oxides (vol\%) & 0.1 & trace & 0.6 & trace & trace & trace & trace & trace & trace & trace & trace & 0.2 & trace \\
\hline
\end{tabular}

The analysis of the samples without stars were by more than 2000 points counting. ${ }^{*}$ The analysis of the samples with stars were by a graphical method using the ImageJ software. Trace, $<0.1$ vol\%.

Table 2. Representative whole rock composition of the Kattadake pyroclastics.

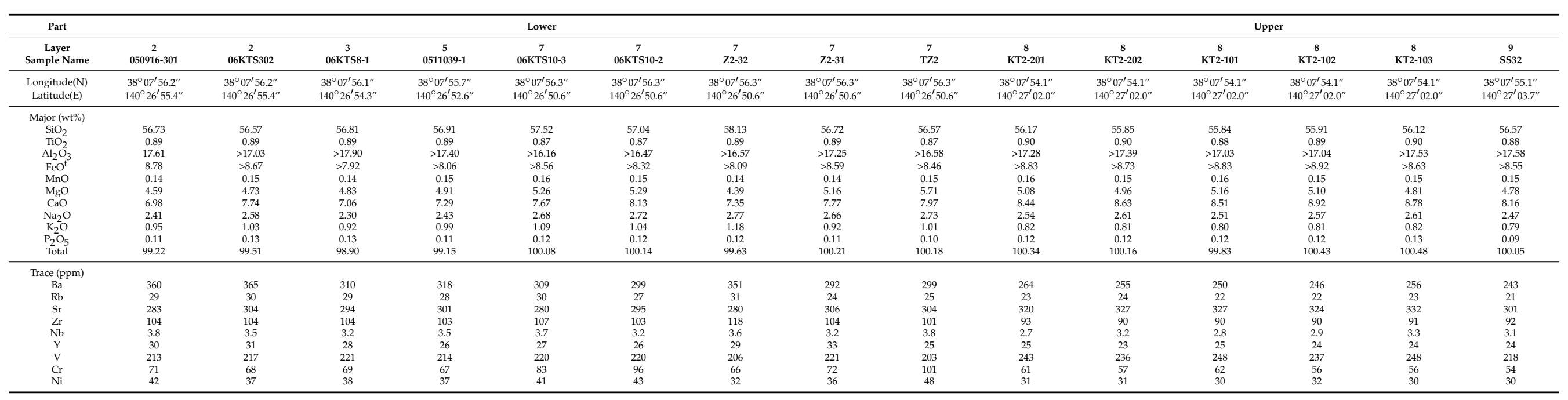


Table 2. Cont.

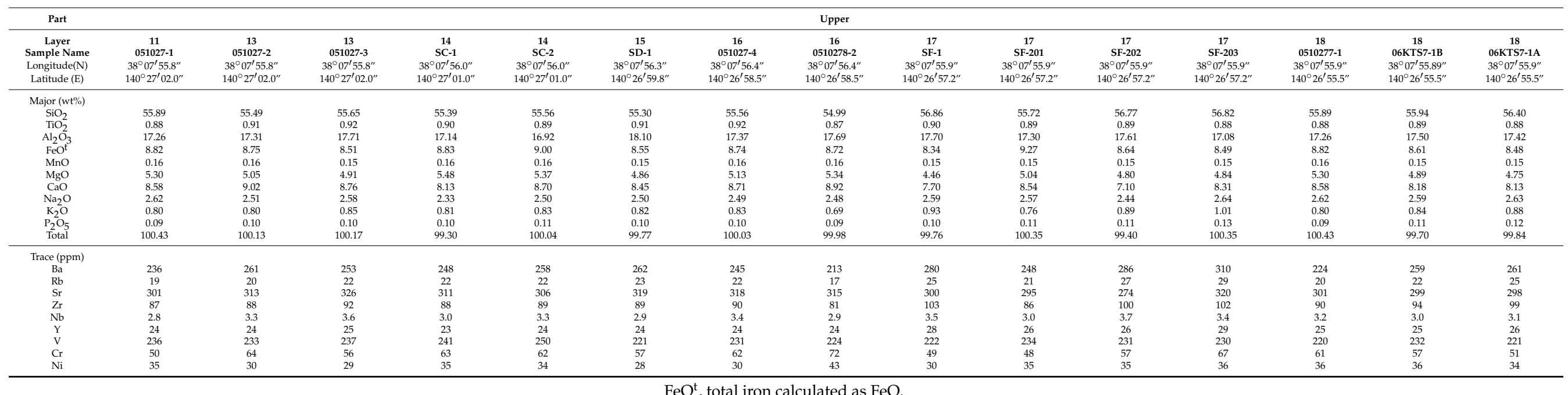

$\mathrm{FeO}^{\mathrm{t}}$, total iron calculated as $\mathrm{FeO}$. 

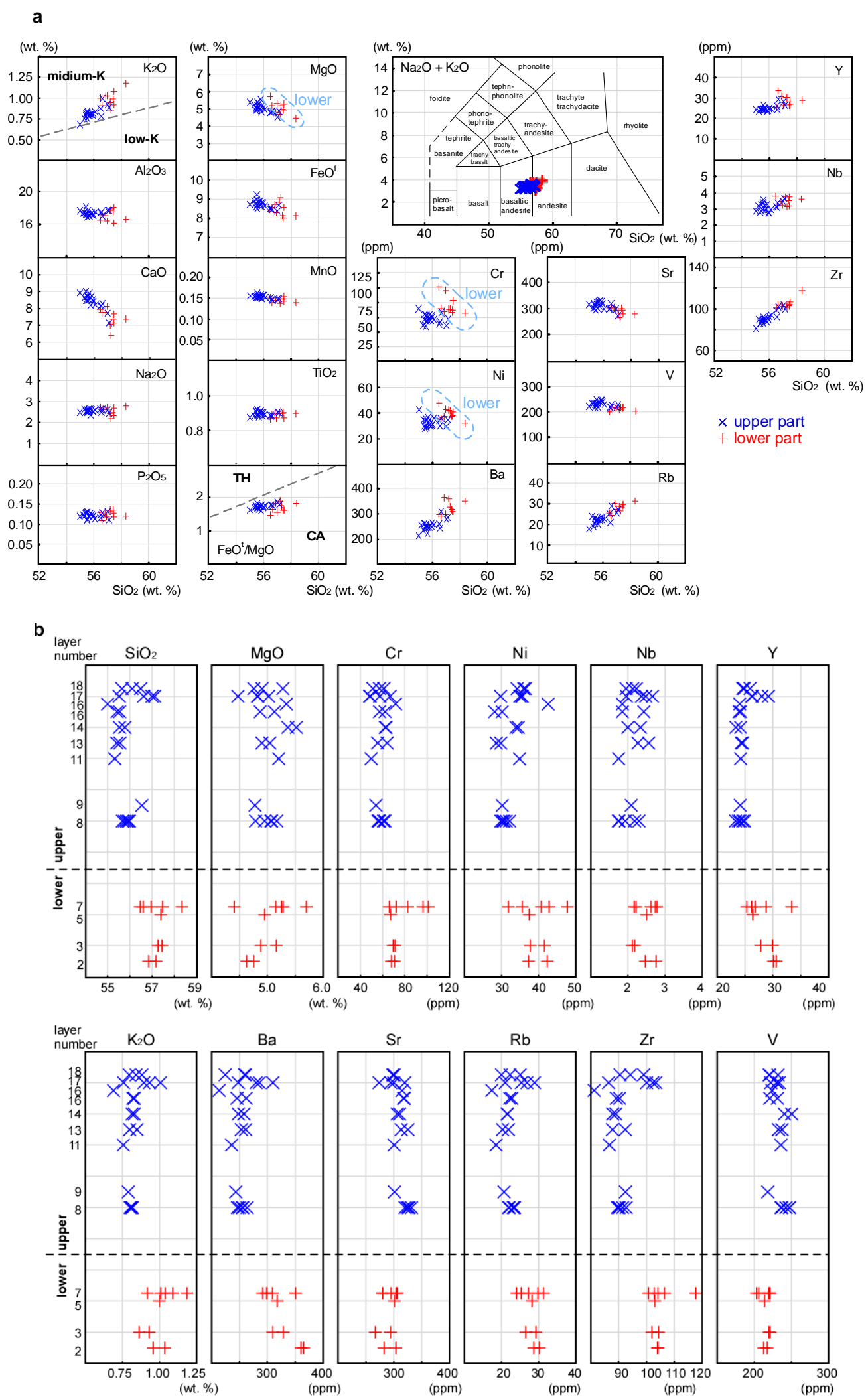

Figure 4. (a) Major and trace element versus $\mathrm{SiO}_{2}$ variation diagrams of samples from the Kattadake pyroclastics. Boundaries defining the low- $\mathrm{K}$ and medium- $\mathrm{K}$ fields in the $\mathrm{K}_{2} \mathrm{O}$ vs. $\mathrm{SiO}_{2}$ diagram and the tholeiite $(\mathrm{TH})$ and calc-alkaline (CA) fields in the $\mathrm{FeO}^{\mathrm{t}} / \mathrm{MgO}$ vs. $\mathrm{SiO}_{2}$ diagram are from Gill 1981 [19] and Miyashiro 1974 [20], respectively. (b) Temporal variations in $\mathrm{SiO}_{2}, \mathrm{MgO}, \mathrm{K}_{2} \mathrm{O}$, and trace element contents of samples from the Kattadake pyroclastics. The layer numbers are the same as in Figure 2. 


\subsection{Textural and Compositional Features of Phenocrysts}

The chemical compositions and the histograms of plagioclase, pyroxene, and olivine phenocrysts are presented in Tables 3-5, Table S1, and Figure 5. Back-scattered electron (BSE) images of representative minerals are shown in Figure 6.

Table 3. Representative chemical compositions of orthopyroxene phenocrysts from samples of the Kattadake pyroclastics.

\begin{tabular}{|c|c|c|c|c|c|c|c|c|c|}
\hline \multirow{2}{*}{$\begin{array}{c}\text { Phenocryst } \\
\text { Type }\end{array}$} & \multicolumn{9}{|c|}{ Orthopyroxene } \\
\hline & \multicolumn{2}{|c|}{ Reversed/Unzoned } & \multicolumn{2}{|c|}{ Reversed/Unzoned } & \multicolumn{2}{|c|}{ Reversed/Unzoned } & \multicolumn{3}{|c|}{ Small } \\
\hline Layer & \multicolumn{2}{|c|}{5} & \multicolumn{2}{|c|}{7} & \multicolumn{2}{|c|}{14} & \multicolumn{3}{|c|}{5} \\
\hline Analysis Date & \multicolumn{2}{|c|}{13 January 2007} & \multicolumn{2}{|c|}{07 February 2004} & \multicolumn{2}{|c|}{29 January 2002} & \multicolumn{3}{|c|}{13 January 2007} \\
\hline Number & $1 C$ & $\mathrm{R}$ & $5 C$ & $\mathrm{R}$ & $20 \mathrm{C}$ & $\mathrm{R}$ & $5 C$ & $\mathrm{C} 2$ & $\mathrm{R}$ \\
\hline Point & Core & Rim & Core & Rim & Core & Rim & Core & Mantle & Rim \\
\hline $\mathrm{SiO}_{2}$ & 53.83 & 54.59 & 53.65 & 53.84 & 52.76 & 54.64 & 53.87 & 54.10 & 54.21 \\
\hline $\mathrm{TiO}_{2}$ & 0.26 & 0.31 & 0.34 & 0.43 & 0.30 & 0.25 & 0.33 & 0.25 & 0.32 \\
\hline $\mathrm{Al}_{2} \mathrm{O}_{3}$ & 0.90 & 0.85 & 1.01 & 1.22 & 1.04 & 1.93 & 1.10 & 1.55 & 0.77 \\
\hline $\mathrm{FeO}$ & 20.84 & 17.80 & 21.58 & 18.80 & 20.82 & 15.41 & 18.08 & 16.70 & 20.05 \\
\hline $\mathrm{MnO}$ & 0.42 & 0.47 & 0.61 & 0.38 & 0.54 & 0.52 & 0.41 & 0.38 & 0.38 \\
\hline $\mathrm{MgO}$ & 22.36 & 25.06 & 21.43 & 23.26 & 22.19 & 26.07 & 23.92 & 25.25 & 22.70 \\
\hline $\mathrm{CaO}$ & 1.94 & 1.83 & 1.99 & 2.07 & 1.95 & 2.24 & 1.88 & 1.73 & 1.85 \\
\hline $\mathrm{Na}_{2} \mathrm{O}$ & 0.02 & 0.02 & 0.02 & 0.08 & 0.05 & 0.19 & 0.05 & 0.06 & 0.02 \\
\hline $\mathrm{K}_{2} \mathrm{O}$ & 0.00 & 0.00 & 0.00 & 0.00 & 0.00 & 0.00 & 0.00 & 0.00 & 0.00 \\
\hline $\mathrm{Cr}_{2} \mathrm{O}_{3}$ & 0.01 & 0.03 & 0.02 & 0.02 & 0.00 & 0.05 & 0.05 & 0.16 & 0.00 \\
\hline $\mathrm{NiO}$ & 0.00 & 0.00 & 0.00 & 0.04 & 0.00 & 0.11 & 0.00 & 0.03 & 0.00 \\
\hline Total & 100.59 & 100.97 & 100.66 & 100.14 & 99.66 & 101.40 & 99.70 & 100.21 & 100.30 \\
\hline $\mathrm{Mg \#}$ & 66 & 72 & 64 & 69 & 66 & 75 & 70 & 73 & 67 \\
\hline
\end{tabular}

Table 4. Representative chemical compositions of clinopyroxenes and olivine phenocrysts from samples of the Kattadake pyroclastics.

\begin{tabular}{|c|c|c|c|c|c|c|c|c|c|c|}
\hline \multirow{5}{*}{$\begin{array}{c}\text { Phenocryst } \\
\text { Layer } \\
\text { Analysis Date } \\
\text { Number } \\
\text { Point }\end{array}$} & \multicolumn{4}{|c|}{ Clinopyroxene } & \multirow{4}{*}{$\begin{array}{c}\text { Phenocryst } \\
\text { Layer } \\
\text { Analysis Date } \\
\text { Number }\end{array}$} & \multicolumn{5}{|c|}{ Olivine } \\
\hline & \multirow{2}{*}{\multicolumn{2}{|c|}{$\begin{array}{c}5 \\
\text { 17 January } 2007\end{array}$}} & \multirow{2}{*}{\multicolumn{2}{|c|}{$\begin{array}{c}5 \\
11 \text { January } 2000\end{array}$}} & & \multirow{2}{*}{\multicolumn{2}{|c|}{$\begin{array}{c}7 \\
\text { 07 February } 2004\end{array}$}} & \multirow{2}{*}{\multicolumn{3}{|c|}{$\begin{array}{c}16 \\
17 \text { November } 2010\end{array}$}} \\
\hline & & & & & & & & & & \\
\hline & $13 \mathrm{C}$ & $\mathrm{R}$ & $5 C$ & $\mathrm{R}$ & & $8 \mathrm{C}$ & $\mathrm{R}$ & $10 \mathrm{C}$ & $\mathrm{C} 2$ & $\mathrm{R}$ \\
\hline & Core & $\operatorname{Rim}$ & Core & Rim & Point & Core & Rim & Core & Mantle & Rim \\
\hline $\mathrm{SiO}_{2}$ & 51.78 & 51.69 & 52.20 & 52.31 & $\mathrm{SiO}_{2}$ & 41.15 & 39.92 & 38.91 & 39.72 & 39.36 \\
\hline $\mathrm{TiO}_{2}$ & 0.53 & 0.61 & 0.53 & 0.55 & $\mathrm{TiO}_{2}$ & 0.00 & 0.01 & 0.00 & 0.00 & 0.01 \\
\hline $\mathrm{Al}_{2} \mathrm{O}_{3}$ & 2.14 & 2.42 & 1.73 & 1.91 & $\mathrm{Al}_{2} \mathrm{O}_{3}$ & 0.01 & 0.01 & 0.03 & 0.02 & 0.01 \\
\hline $\mathrm{FeO}$ & 12.24 & 9.65 & 11.55 & 9.25 & $\mathrm{FeO}$ & 15.23 & 20.46 & 23.21 & 18.18 & 20.25 \\
\hline $\mathrm{MnO}$ & 0.34 & 0.28 & 0.31 & 0.32 & $\mathrm{MnO}$ & 0.24 & 0.38 & 0.38 & 0.29 & 0.27 \\
\hline $\mathrm{MgO}$ & 14.13 & 15.05 & 14.32 & 14.94 & $\mathrm{MgO}$ & 44.64 & 40.32 & 38.79 & 43.31 & 41.28 \\
\hline $\mathrm{CaO}$ & 18.17 & 18.73 & 19.37 & 19.50 & $\mathrm{CaO}$ & 0.15 & 0.20 & 0.13 & 0.17 & 0.15 \\
\hline $\mathrm{Na}_{2} \mathrm{O}$ & 0.21 & 0.21 & 0.20 & 0.22 & $\mathrm{Na}_{2} \mathrm{O}$ & 0.00 & 0.01 & 0.00 & 0.00 & 0.01 \\
\hline $\mathrm{K}_{2} \mathrm{O}$ & 0.00 & 0.00 & 0.00 & 0.00 & $\mathrm{~K}_{2} \mathrm{O}$ & 0.00 & 0.00 & 0.00 & 0.00 & 0.00 \\
\hline $\mathrm{Cr}_{2} \mathrm{O}_{3}$ & 0.03 & 0.11 & 0.01 & 0.07 & $\mathrm{Cr}_{2} \mathrm{O}_{3}$ & 0.03 & 0.00 & 0.01 & 0.00 & 0.00 \\
\hline $\mathrm{NiO}$ & 0.05 & 0.02 & 0.04 & 0.00 & $\mathrm{NiO}$ & 0.09 & 0.06 & 0.03 & 0.09 & 0.15 \\
\hline Total & 99.62 & 98.77 & 100.27 & 99.07 & Total & 101.54 & 101.39 & 101.48 & 101.79 & 101.49 \\
\hline Mg\# & 67 & 74 & 69 & 74 & $\mathrm{Fo} \%$ & 84 & 78 & 75 & 81 & 78 \\
\hline
\end{tabular}


Table 5. Representative chemical compositions of plagioclase phenocrysts from samples of the Kattadake pyroclastics.

\begin{tabular}{|c|c|c|c|c|c|c|c|c|c|c|c|c|c|c|c|c|c|}
\hline $\begin{array}{l}\text { Phenocryst } \\
\text { Type }\end{array}$ & \multicolumn{3}{|c|}{ Oscillatory } & \multicolumn{3}{|c|}{ Oscillatory } & \multicolumn{6}{|c|}{ Oscillatory Plagioclase } & \multicolumn{2}{|c|}{ Clear/Dissolved } & \multicolumn{3}{|c|}{ Clear/Dissolved } \\
\hline $\begin{array}{c}\text { Layer } \\
\text { Analysis Date }\end{array}$ & \multicolumn{3}{|c|}{$\begin{array}{c}5 \\
12 \text { December } 2006\end{array}$} & \multicolumn{3}{|c|}{$\begin{array}{c}9 \\
11 \text { November } 2006\end{array}$} & \multicolumn{3}{|c|}{$\begin{array}{c}14 \\
13 \text { October } 2006\end{array}$} & \multicolumn{3}{|c|}{$\begin{array}{c}16 \\
11 \text { October } 2006\end{array}$} & \multicolumn{2}{|c|}{$\begin{array}{c}7 \\
30 \text { August } 2006\end{array}$} & \multicolumn{3}{|c|}{$\begin{array}{c}7 \\
11 \text { October } 2006\end{array}$} \\
\hline $\begin{array}{l}\text { Number } \\
\text { Point }\end{array}$ & $\begin{array}{c}12 \mathrm{C} \\
\text { An-rich }\end{array}$ & $\begin{array}{c}\text { C2 } \\
\text { An-poor }\end{array}$ & $\begin{array}{c}\mathrm{R} \\
\mathrm{Rim}\end{array}$ & $\begin{array}{c}5 \mathrm{C} \\
\text { An-poor }\end{array}$ & $\begin{array}{c}\mathrm{C} 2 \\
\text { An-rich }\end{array}$ & $\begin{array}{c}\mathrm{R} \\
\mathrm{Rim}\end{array}$ & $\begin{array}{c}1 \mathrm{C} \\
\text { An-poor }\end{array}$ & $\begin{array}{c}\mathrm{C} 2 \\
\text { An-rich }\end{array}$ & $\begin{array}{c}\mathrm{R} \\
\mathrm{Rim}\end{array}$ & $\begin{array}{c}8 \mathrm{C} \\
\text { An-poor }\end{array}$ & $\begin{array}{c}\mathrm{C} 2 \\
\text { An-rich }\end{array}$ & $\begin{array}{c}\mathrm{R} \\
\mathrm{Rim}\end{array}$ & $\begin{array}{l}12 \mathrm{C} \\
\text { Core }\end{array}$ & $\begin{array}{c}\mathrm{R} \\
\mathrm{Rim}\end{array}$ & $\begin{array}{c}3 \mathrm{C} \\
\text { Core }\end{array}$ & $\begin{array}{c}\mathrm{C} 2 \\
\text { Mantle }\end{array}$ & $\begin{array}{c}\mathrm{R} \\
\mathrm{Rim}\end{array}$ \\
\hline $\mathrm{SiO}_{2}$ & 48.57 & 51.71 & 49.62 & 51.04 & 47.29 & 53.40 & 52.19 & 49.51 & 51.09 & 49.69 & 48.14 & 48.60 & 45.08 & 51.94 & 44.33 & 52.27 & 52.25 \\
\hline $\mathrm{Al}_{2} \mathrm{O}_{3}$ & 30.46 & 28.63 & 29.72 & 28.75 & 31.81 & 28.43 & 28.41 & 30.50 & 29.16 & 29.06 & 30.30 & 30.27 & 33.74 & 29.06 & 34.03 & 27.81 & 28.06 \\
\hline $\mathrm{Fe}_{2} \mathrm{O}_{3}$ & 0.78 & 0.76 & 0.83 & 0.99 & 0.88 & 0.99 & 0.94 & 0.88 & 0.93 & 0.82 & 0.85 & 0.98 & 0.63 & 1.11 & 0.58 & 0.81 & 0.96 \\
\hline $\mathrm{MgO}$ & 0.08 & 0.09 & 0.11 & 0.11 & 0.07 & 0.09 & 0.10 & 0.10 & 0.11 & 0.10 & 0.08 & 0.08 & 0.08 & 0.17 & 0.04 & 0.10 & 0.09 \\
\hline $\mathrm{CaO}$ & 14.67 & 12.66 & 13.96 & 13.36 & 15.95 & 12.33 & 12.79 & 14.76 & 13.25 & 13.84 & 14.88 & 14.70 & 18.00 & 13.57 & 18.62 & 11.85 & $11.5 \mathrm{c}$ \\
\hline $\mathrm{K}_{2} \mathrm{O}$ & 0.11 & 0.17 & 0.11 & 0.15 & 0.07 & 0.24 & 0.17 & 0.12 & 0.20 & 0.10 & 0.09 & 0.09 & 0.00 & 0.17 & 0.02 & 0.20 & 0.29 \\
\hline Total & 97.37 & 97.75 & 97.50 & 97.80 & 97.95 & 99.37 & 98.47 & 98.89 & 98.37 & 97.09 & 97.16 & 97.43 & 98.69 & 99.46 & 98.37 & 97.07 & 97.45 \\
\hline An $\%$ & 74 & 65 & 71 & 68 & 82 & 63 & 64 & 72 & 66 & 68 & 74 & 75 & 90 & 68 & 93 & 61 & 59 \\
\hline
\end{tabular}

An, anorthite; $\mathrm{Mg \# ,} 100 \times\{\mathrm{Mg} /(\mathrm{Mg}+\mathrm{Fe})\} ;$ Fo, forsterite. 


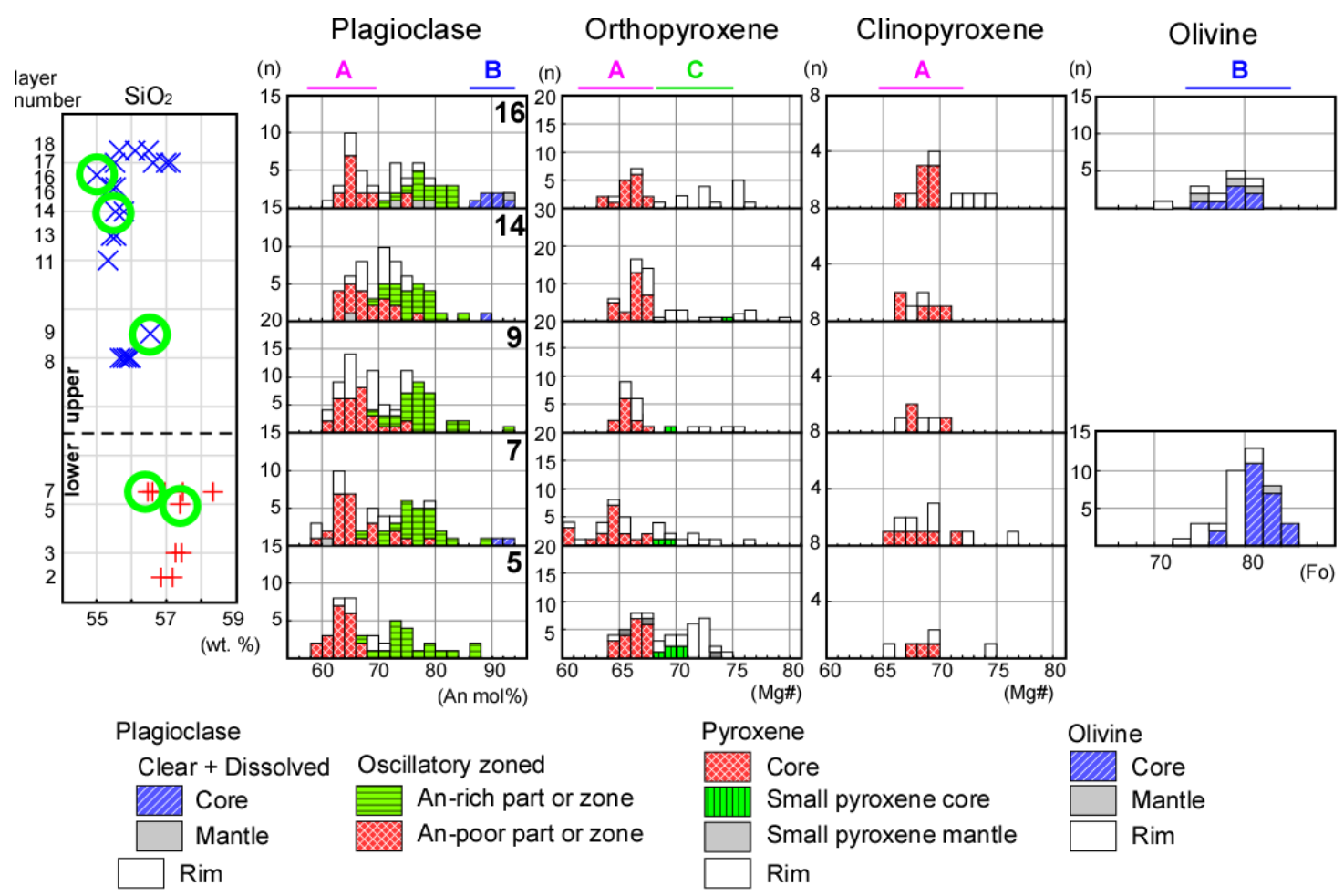

Figure 5. The histograms of the compositions of plagioclase, orthopyroxene, clinopyroxene, and olivine phenocrysts. Solid lines $\mathrm{A}, \mathrm{B}$, and $\mathrm{C}$ show the compositional ranges of the $\mathrm{A}, \mathrm{B}$, and $\mathrm{C}$ groups of phenocrysts. Temporal change of bulk $\mathrm{SiO}_{2}$ contents is in the left. The samples for the analyses of mineral chemistry were identified by the green circle. The layer numbers are the same as in Figure 2. An, Anorthite; $\mathrm{Mg} \#$ and Fo, $100 \times[\mathrm{Mg} /(\mathrm{Fe}+\mathrm{Mg})]$; n, number of analyses.

\subsubsection{Olivine}

All olivine phenocrysts (up to $6 \mathrm{~mm}$ ) are subhedral and show somewhat skeletal texture (Figure 6a,b). Some olivine phenocrysts contain minor amount of hollow $(\sim 100 \mu \mathrm{m})$ in its core part. The phenocrysts usually show normal zoning with $\mathrm{Mg}$-richer $\left(\mathrm{Fo}_{75-84}\right)$ cores and overgrowths of thin $\mathrm{Mg}$-poorer $\left(\mathrm{Fo}_{66-79}\right)$ rims (Figure 5). Whereas the phenocrysts having ca. $100 \mu \mathrm{m}$-thick Mg-richer (Fo-89-83) mantles surrounding their cores (Fo $74-78$ ) (Figure $6 \mathrm{~b}$ ) are occasionally found in samples from the upper part. The Fo content of olivine phenocryst core tends to be higher in the lower part samples $(\sim 84)$ than in the upper part samples ( 81) (Figure 5). The phenocrysts from lower part include $\mathrm{Cr}$-spinel inclusions (up to $50 \mu \mathrm{m}$ in diameter) showing circular or rhomboidal shaped in core part. The olivines occurring in the glomerocryst with the plagioclase have $\mathrm{Fo}_{\sim 83}$ contents in core, but $\mathrm{Fo}_{<81}$ in the contact.

\subsubsection{Clinopyroxene}

All clinopyroxene phenocrysts (up to $8 \mathrm{~mm}$ in size) are euhedral to subhedral (Figure 6c). The core contains circular to irregularly shaped melt inclusions (up to $500 \mu \mathrm{m}$ ). Each phenocryst grain is usually Mg-poor $(\mathrm{Mg} \#=67-71)$ and compositionally homogeneous, whereas some show Mg-richer (Mg\# $=72-76$ ) rim overgrowths $\sim 100 \mu \mathrm{m}$ from the margins.

\subsubsection{Orthopyroxene}

Orthopyroxene phenocrysts (up to $7 \mathrm{~mm}$ ) occur with two textural types: reversed/unzoned and small. More than $90 \%$ of orthopyroxene belongs to reversed/unzoned type.

The reversed/unzoned type is euhedral to subhedral (Figure 6d) and contains circular or irregularly shaped melt inclusions (up to $300 \mu \mathrm{m}$ ) in its cores. This type has Mg-poor 
$(\mathrm{Mg \#}=61-67)$ core and usually has higher-Mg zoned rim (up to 78 in Mg\#) $30 \mu \mathrm{m}$ from the margin. The phenocrysts showing resorbed irregular boundary between Mg-poor core and higher Mg-zoned rim ( $300 \mu \mathrm{m}$ from the margin) are occasionally found (Figure $6 \mathrm{e}$ ). The zoned rim texture and compositions of these phenocrysts are similar to that of small type as described below.
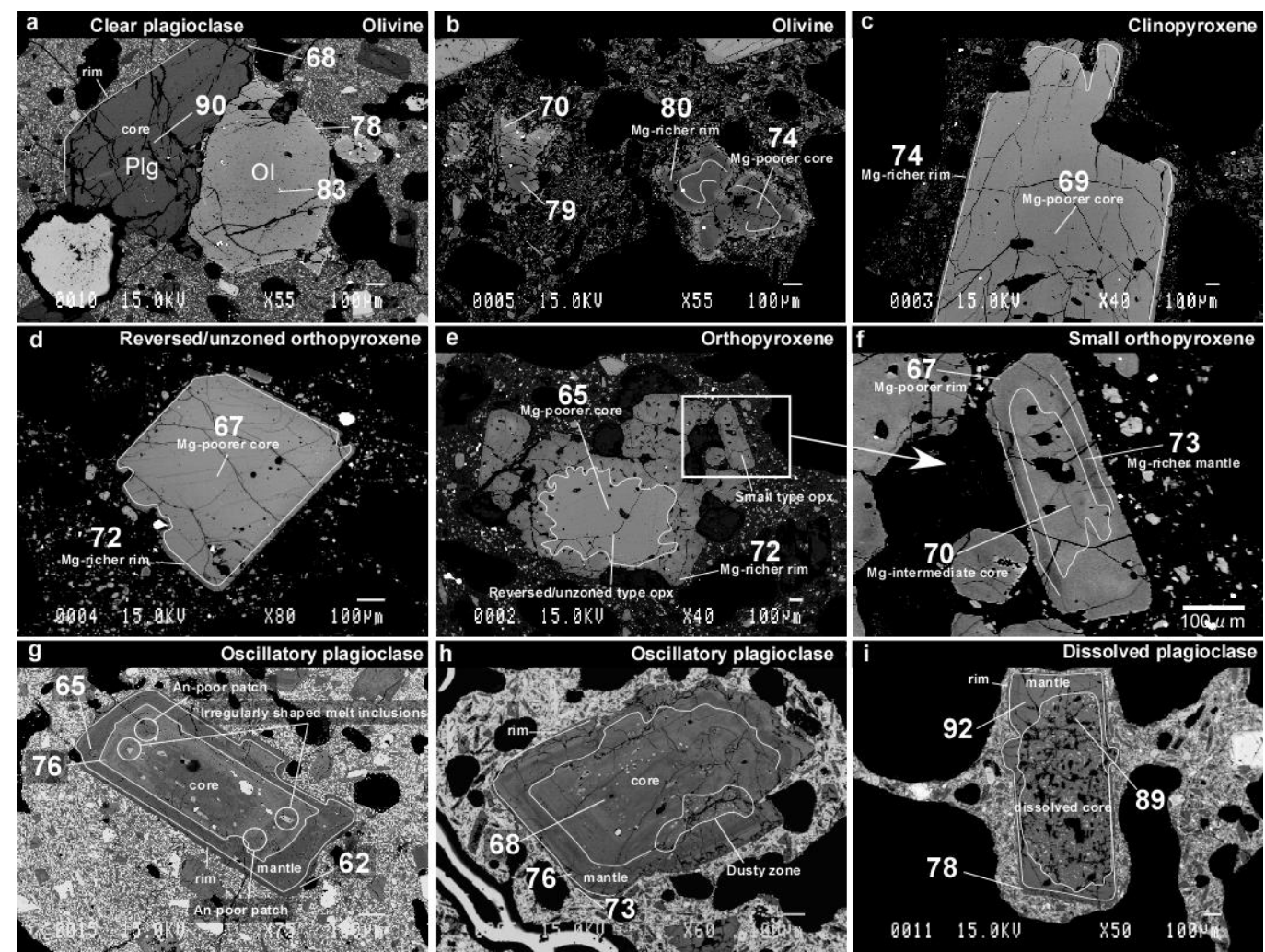

Figure 6. BSE images of representative crystals in samples from the Kattadake pyroclastics. (a) A Fo rich olivine, constituting a glomerocryst with a clear type plagioclase. (b) Normal and reverse zoned olivine phenocrysts. (c) A clinopyroxene phenocryst having Mg-poor core and Mg-rich thin rim. (d) A reversed/unzoned orthopyroxene having Mg-rich thin rim. (e) A reversed/unzoned orthopyroxene having $\mathrm{Mg}$-rich thick rim and a small type orthopyroxene. (f) Close-up of the small type orthopyroxene in (e). (g) An oscillatory zoned plagioclase having irregular shaped melt inclusions and An-poor patches. (h) An oscillatory zoned plagioclase. (i) A dissolved plagioclase. Numbers in photographs indicate Fo, Mg\#, or An contents of analyzed points. (a,d,e,f,g) are from lower part samples and $(\mathbf{b}, \mathbf{c}, \mathbf{h}, \mathbf{i})$ are from upper part samples.

The small type (up to $0.7 \mathrm{~mm}$ ) (Figure 6e,f) is anhedral to subhedral. The crystal has core with moderate amount of tubular to irregularly shaped melt inclusions $(\sim 100 \mu \mathrm{m})$. The core contains minor amount of hollow $(\sim 100 \mu \mathrm{m})$. The core is surrounded by a thin mantle $(\sim 20 \mu \mathrm{m})$ and has an overgrowth rim that is $30 \mu \mathrm{m}$ or less in thickness. The Mg\# values of the cores, mantles, and rims vary between 68-70, 67-73, and 67-71 of Mg\#, respectively (Figure 5).

\subsubsection{Plagioclase}

Plagioclase phenocrysts (up to $8 \mathrm{~mm}$ in size) are divided into three textural types: oscillatory zoned, clear, and dissolved types. The texture of these types is similar to the texture type 1 (High Amplitude-Low Frequency; HALF) or combination of 1 (HALF) and 3, 1 (Low Amplitude-High Frequency; LAHF), and 2 or 4 described by Viccaro et al. 2010 [21], respectively. More than $80 \%$ plagioclase belongs to oscillatory zoned type.

Oscillatory zoned plagioclase (Figure $6 \mathrm{~g}, \mathrm{~h}$ ) is subhedral, with diffuse and symmetrical oscillatory and/or patchy zoned cores. In terms of this type, we analyzed the An-poorest and An-richest zones in the core for each grain. Compositions of An-poor and An-rich 
zones are mostly $\mathrm{An}_{58-70}$ and $\mathrm{An}_{70-85}$, respectively (Figure 5). The amplitudes and steps of these oscillations vary. They usually exceed $10 \mathrm{~mol} \%$ and several tens to $100 \mu \mathrm{m}$ (HALF). The An-poor zones in the cores are wider than the An-rich zones and the zones sometimes become discontinuous and patchy (Figure $6 \mathrm{~g}, \mathrm{~h}$ ). Circular to irregularly shaped melt inclusions (up to $100 \mu \mathrm{m}$ ) are observed in cores (Figure $6 \mathrm{~g}, \mathrm{~h}$ ). The core outlines sometimes show irregular and rounded surfaces surrounded by oscillatory zoned mantles with or without dusty zones (Tsuchiyama 1985 [22]) (Figure 6h), which are mainly composed of fine melt inclusions $(20 \mu \mathrm{m})$ and An-rich $\left(\mathrm{An}_{70-90}\right)$ plagioclases. This type usually has thin (less than $20 \mu \mathrm{m}$ wide) and clear rim. Compositions of the rim are $\mathrm{An}_{60-75}$.

Clear plagioclase (Figure 6a) is euhedral and sometimes presents in glomerocrystals

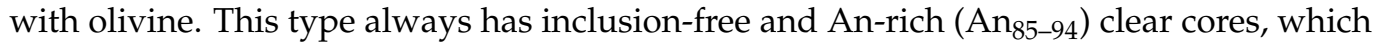
show LAHF oscillatory zoning. Cores are sometimes surrounded by An-poorer mantles $\left(\mathrm{An}_{60-80}\right.$, less than $500 \mu \mathrm{m}$ wide), which have textures resembling those of oscillatory zoned plagioclases. Rim compositions of this type are $\mathrm{An}_{60-75}$.

Dissolved plagioclase (Figure 6i) is subhedral. The core is filled by many small $(\sim 10 \mu \mathrm{m})$ melt inclusions and abundant hollows with relicts of plagioclase. This type always has An-rich $\left(\mathrm{An}_{85-94}\right)$ core and sometimes has mantles, whose textures resemble to cores of oscillatory zoned or clear plagioclases. Rim compositions of this type are $\mathrm{An}_{60-75}$.

\section{Discussion}

\subsection{Mixing of Two End-Member Magmas Produced the Variable Petrological Features of the Kattadake Pyroclastics}

To interpret the variations in calc-alkaline andesitic magmas, different hypotheses have been proposed, fractional crystallization of basaltic magma, crustal assimilation and fractional crystallization of basaltic magma, partial melting of the basaltic lower crust, and magma mixing between mafic and felsic magmas (e.g., Andújar et al. 2016 [23], Hildreth 2004 [24], and Marsh 1989 [25]). In the case of the Kattadake pyroclastics, the following features support the magma mixing hypothesis: (1) Disequilibrium phenocryst assemblages in same rock samples, such as Mg-rich olivine vs. Mg-poor pyroxenes and An-rich vs. An-poor plagioclase phenocrysts (Figure 5); (2) Mg-rich rims observed in pyroxene and olivine phenocrysts (Figures 5 and 6); and (3) The whole-rock compositions of each of the lower and upper part show linear trends in most variation diagrams (Figure 4).

The phenocrystic mafic minerals in the Kattadake pyroclastics show a wide compositional variation as described in the textural and compositional features of phenocrysts section. Based on the olivine-orthopyroxene and olivine-clinopyroxene Fe-Mg exchange equilibria by Matsui and Nishizawa 1974 [26] and Obata et al. 1974 [27], these mafic minerals can be classified into three groups. $\mathrm{Mg}$-poor reversed/unzoned orthopyroxene $(\mathrm{Mg \#}=$ ca. $62-67)$ and clinopyroxene $(\mathrm{Mg \#}=$ ca. $65-72)$ are grouped to A. Olivine $\left(\mathrm{Fo}_{74-84}\right)$ is grouped to $\mathrm{B}$. The small orthopyroxene $(\mathrm{Mg \#}=\mathrm{ca} .70)$ is grouped to $\mathrm{C}$.

Based on their compositional features, the group A, B, and C phenocrysts are interpreted as basically derived from the felsic end-member magma, mafic end-member magma, and the mixed magma, respectively. $\mathrm{Mg}$-richer rims of orthopyroxene and clinopyroxene were formed during mixing with mafic magma.

The clear and dissolved plagioclases are assigned to group B, because of the high An content of their cores. These would precipitate from mafic magma. The dissolution of the dissolved plagioclase occurred during the ascent of $\mathrm{H}_{2} \mathrm{O}$-undersaturated mafic magma (Humphreys et al. 2006 [28]; Viccaro et al. 2010 [21]). On the other hand, the An range of the oscillatory zoned plagioclase is sometimes large $\left(\mathrm{An}_{58-70}\right.$ to $\left.\mathrm{An}_{70-85}\right)$. The HALF oscillatory zoning in oscillatory zoned plagioclase cannot be caused by crystallization kinetic effects, which typically cause LAHF oscillatory zoning similar to that in the clear plagioclase. Cyclic changes in the surrounding magma conditions or convective movement in the magma chamber under heterogeneous $\mathrm{H}_{2} \mathrm{O}$ conditions (e.g., Viccaro et al. 2010 [21]) are required for the formation of the HALF zoning. It is probable that the shallow chamber is not always convective, thus the cyclicity could have been caused by repeated injections of mafic magma into the shallow magma chamber. The An-richer zones formed from the 
intermediate magma, while the An-poor zones formed from andesitic magma. After the injection, plagioclase grains gained the An-richer zone and settled again in the andesitic magma. Therefore, the An poorer and richer parts of the oscillatory zoned plagioclase can be assigned to group A and C, respectively. The discontinuous oscillation and patchy texture would be formed by resorption and precipitation during heating of the injected mafic magmas and subsequent cooling. The dusty texture was formed during mixing with mafic magma.

\subsection{Composition and T-P-H $\mathrm{H}_{2} \mathrm{O}$ Conditions of the Felsic End-Member Magma}

The group A compositions of phenocrysts are always similar An ( $\left.\mathrm{An}_{58-70}\right)$ contents and Mg\# (62-67 Mg\# for orthopyroxene, 65-72 Mg\# for clinopyroxene) through the pyroclastic succession (Figure 5), which suggests that the felsic end-member magma had a similar composition prior to the arrival of the mafic magma. The $\mathrm{Cr}-\mathrm{Ni}-\mathrm{MgO}$ trends of lower and upper parts converge at high $\mathrm{SiO}_{2}$ whereas are split at lower $\mathrm{SiO}_{2}$ part, which also supports the fact that the felsic end-member magma did not change in composition through the formation of the Kattadake pyroclastics. We inferred the bulk composition and $\mathrm{P}-\mathrm{H}_{2} \mathrm{O}$ conditions of the felsic end-member magma using the rhyolite-MELTS program (Gualda et al., 2012 [29]). At first, the potential whole rock compositional data sets (having 59, 60, 61, 62 , and $63 \mathrm{wt} \% \mathrm{SiO}_{2}$ ) of the felsic end-member were estimated by using the mixing trends in the $\mathrm{SiO}_{2}$ variation diagrams. An example of determining $\mathrm{K}_{2} \mathrm{O}$ contents in the $\mathrm{K}_{2} \mathrm{O}-\mathrm{SiO}_{2}$ diagram is shown in Figure 7. The complete data sets are presented in Table 6. By inputting the data sets into the rhyolite-MELTS program, we obtained equilibrium precipitation mineral assemblages and the chemical compositions of the minerals for various $\mathrm{P}-\mathrm{H}_{2} \mathrm{O}$ conditions. In the calculations, the ferric-ferrous ratio was calculated by the method of Sack et al. 1980 [30], NNO buffer condition was assumed based on Ban et al. 2008 [31] where the NNO buffer was estimated for the felsic magma condition of the basaltic andesites from the youngest stage of the Zao volcano, and the temperature was fixed to $960-980{ }^{\circ} \mathrm{C}$, which was estimated by applying a two-pyroxene thermometer (Brey and Köhler 1990 [32]) to the core compositions of group $\mathrm{C}$ pyroxene pairs. We constrained the range of compositions and $\mathrm{P}-\mathrm{H}_{2} \mathrm{O}$ conditions to satisfy the equilibrium precipitation of $\mathrm{An}$ and $\mathrm{Mg} \#$ poor phenocrysts (An $62-66$ plagioclase + 64-66 Mg\# orthopyroxene + 66-69 Mg\# clinopyroxene + magnetite) (Figure 8). The obtained bulk silica content is 59-61 wt \%, high-silica andesite. The ranges of pressure and water contents of the magma are 1.9-3.5 kb and 1.9-3.4 wt\%. These results were graphically represented in Figure 8. Compositions and T-P- $\mathrm{H}_{2} \mathrm{O}$ conditions of the felsic end-member magma are summarized in Table 6.

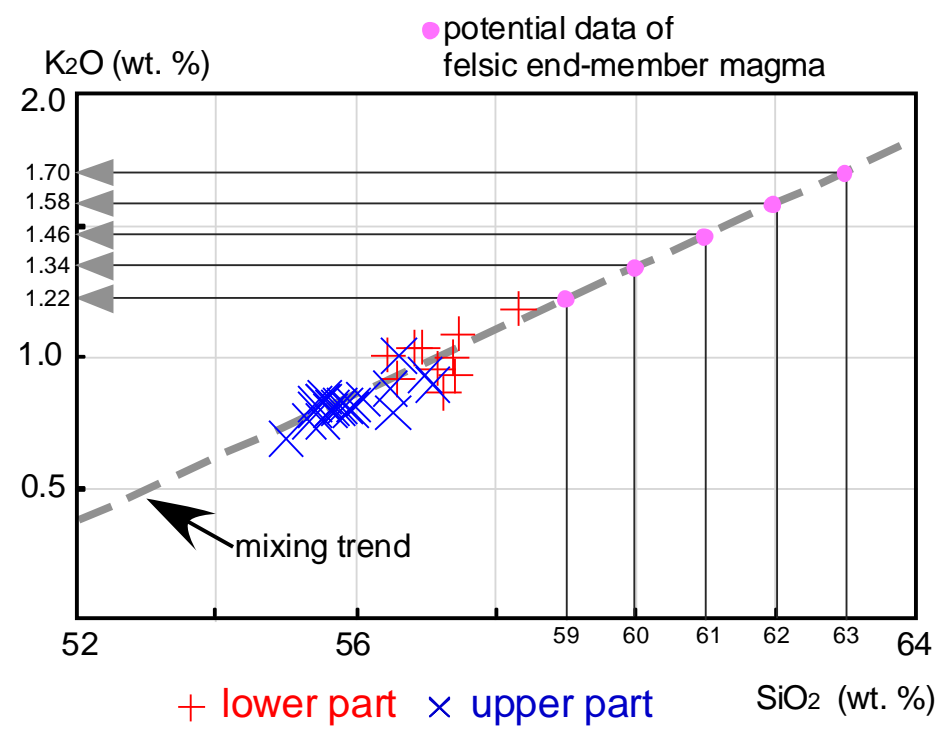

Figure 7. $\mathrm{K}_{2} \mathrm{O}-\mathrm{SiO}_{2}$ diagram showing an example of determination of $\mathrm{K}_{2} \mathrm{O}$ contents in datasets for MELTS calculation of the felsic end-member composition. See text for details. 
Table 6. Estimated bulk compositions and properties of two end-members with potential data sets for the felsic end-member of the Kattadake pyroclastics.

\begin{tabular}{|c|c|c|c|c|c|c|c|c|}
\hline & \multicolumn{3}{|c|}{ Estimated End-Member Compositions } & \multicolumn{5}{|c|}{ Potential Data Sets for the Felsic End-Member } \\
\hline & Felsic & $\begin{array}{l}\text { Mafic } \\
\text { (Lower) }\end{array}$ & $\begin{array}{l}\text { Mafic } \\
\text { (Upper) }\end{array}$ & Felsic 1 & Felsic 2 & Felsic 3 & Felsic 4 & Felsic 5 \\
\hline \multicolumn{9}{|l|}{$\begin{array}{l}\text { Major } \\
(w t \%)\end{array}$} \\
\hline $\mathrm{SiO}_{2}$ & $59.00-61.00$ & 49.40 & 51.80 & 59.00 & 60.00 & 61.00 & 62.00 & 63.00 \\
\hline $\mathrm{TiO}_{2}$ & $0.89-0.89$ & 0.90 & 0.90 & 0.89 & 0.89 & 0.89 & 0.90 & 0.90 \\
\hline $\mathrm{Al}_{2} \mathrm{O}_{3}$ & $15.60-16.20$ & 19.00 & 18.70 & 16.20 & 15.90 & 15.60 & 15.30 & 15.00 \\
\hline $\mathrm{FeO}^{\mathrm{t}}$ & $7.65-8.05$ & 9.70 & 9.50 & 8.05 & 7.85 & 7.65 & 7.45 & 7.25 \\
\hline $\mathrm{MnO}$ & $0.13-0.14$ & 0.20 & 0.20 & 0.14 & 0.13 & 0.13 & 0.12 & 0.12 \\
\hline $\mathrm{MgO}$ & $3.40-4.20$ & 9.10 & 6.50 & 4.20 & 3.80 & 3.40 & 3.00 & 2.60 \\
\hline $\mathrm{CaO}$ & $6.60-7.20$ & 10.00 & 10.20 & 7.20 & 6.90 & 6.60 & 6.30 & 6.00 \\
\hline $\mathrm{Na}_{2} \mathrm{O}$ & $2.85-3.09$ & 1.60 & 2.10 & 2.85 & 2.97 & 3.09 & 3.21 & 3.33 \\
\hline $\mathrm{K}_{2} \mathrm{O}$ & $1.22-1.46$ & 0.10 & 0.20 & 1.22 & 1.34 & 1.46 & 1.58 & 1.70 \\
\hline $\mathrm{P}_{2} \mathrm{O}_{5}$ & $0.13-0.13$ & 0.10 & 0.10 & 0.13 & 0.13 & 0.13 & 0.14 & 0.14 \\
\hline \multicolumn{9}{|l|}{$\begin{array}{l}\text { Trace } \\
\text { (ppm) }\end{array}$} \\
\hline $\mathrm{Ba}$ & 450 & 30 & 70 & & & & & \\
\hline $\mathrm{Rb}$ & 40 & 2 & 6 & & & & & \\
\hline $\mathrm{Sr}$ & 200 & 450 & 400 & & & & & \\
\hline $\mathrm{Zr}$ & 150 & 15 & 40 & & & & & \\
\hline $\mathrm{Nb}$ & 5.1 & 1.5 & 1.0 & & & & & \\
\hline Y & 33 & 15 & 18 & & & & & \\
\hline $\mathrm{V}$ & 180 & 300 & 280 & & & & & \\
\hline $\mathrm{Cr}$ & 45 & 140 & 75 & & & & & \\
\hline $\mathrm{Ni}$ & 28 & 60 & 37 & & & & & \\
\hline Temp. $\left({ }^{\circ} \mathrm{C}\right)$ & $960-980$ & $1170 \pm 20$ & $1100 \pm 30$ & & & & & \\
\hline $\begin{array}{l}\text { Pressure } \\
(\mathrm{kb})\end{array}$ & $1.9-3.5$ & $1.0-4.7$ & $1.0-2.9$ & & & & & \\
\hline Water (\%) & $1.9-3.4$ & $1.3-2.8$ & $1.7-2.6$ & & & & & \\
\hline
\end{tabular}

All oxide values are normalized to $100 \%$ and $\mathrm{FeO}^{\mathrm{t}}$, total iron calculated as $\mathrm{FeO}$.

\subsection{Composition and T-P- $\mathrm{H}_{2} \mathrm{O}$ Conditions of the Mafic End-Member Magma}

As described above, $\mathrm{Cr}-\mathrm{Ni}-\mathrm{MgO}$ trends of lower and upper parts are splitting off with decreasing $\mathrm{SiO}_{2}$ content, thus the mafic end-member magma composition was different between lower and upper parts. To determine the mafic end-member compositions which crystallized $\mathrm{Fo}_{83-84}$ olivine in the lower part and $\mathrm{Fo}_{81}$ olivine in the upper part, we used Fe-Mg exchange equilibrium $K_{D}$ between olivine and liquid by Sisson and Grove 1993 [33]. The ferric-ferrous ratio was calculated using the method of Sack et al. 1981 [30]. The oxygen fugacity was assumed at NNO based on Ban et al. 2008 [31] Using obtained Fe/Mg and the whole rock trends of the $\mathrm{SiO}_{2}$ variation diagrams, we determined the contents of $\mathrm{SiO}_{2}$ and the compositions of the other elements of the mafic end-members. We obtained bulk $\mathrm{SiO}_{2}$ contents of ca. $49.4 \mathrm{wt} \%$ and $51.8 \mathrm{wt} \%$ for the mafic end-members of lower and upper parts, respectively. These are basalts. The obtained elemental compositions of the mafic end-members of lower and upper parts are presented in Table 6. Using the rhyoliteMELTS program, the temperature, pressure, and water contents were determined to be $1170 \pm 20^{\circ} \mathrm{C}, 1.0-4.7 \mathrm{~kb}$, and $1.3-2.8 \mathrm{wt} \%$ and $1100 \pm 30^{\circ} \mathrm{C}, 1.0-2.9 \mathrm{~kb}$, and $1.7-2.6 \mathrm{wt} \%$, respectively, to satisfy the equilibrium precipitation of the group $\mathrm{B}$ phenocrysts of $\mathrm{Fo}_{83-84}$ olivine for lower part and high-An plagioclase $+\mathrm{Fo}_{81}$ olivine for upper part as near-liquidus phases. The calculations indicated that $\mathrm{Fo}_{83-84}$ olivine cannot precipitate with high-An plagioclase. $\mathrm{Fo}_{83-84}$ olivine is a solo near-liquidus phase of the mafic end-member of the lower part. Summary of the petrological features of the mafic end-member magmas is in Table 6. 


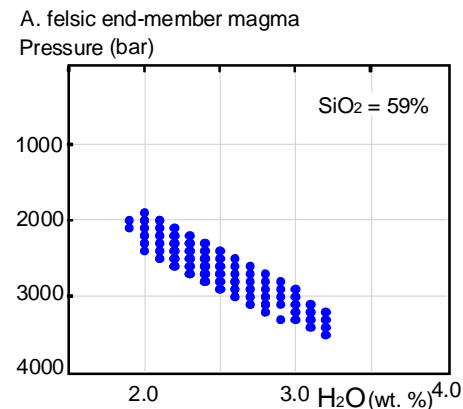

B. mafic end-member magma of lower part Pressure (bar)

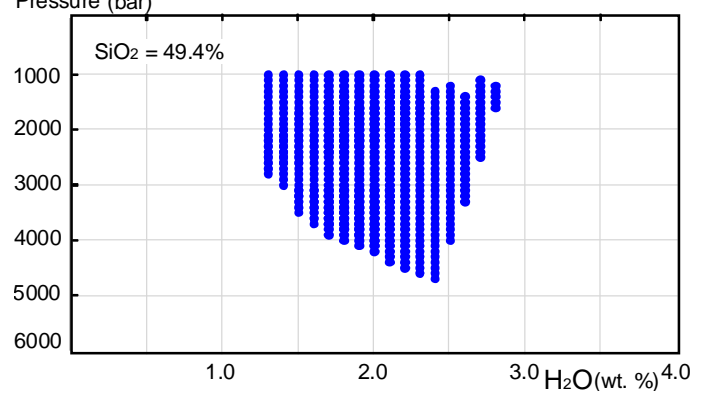

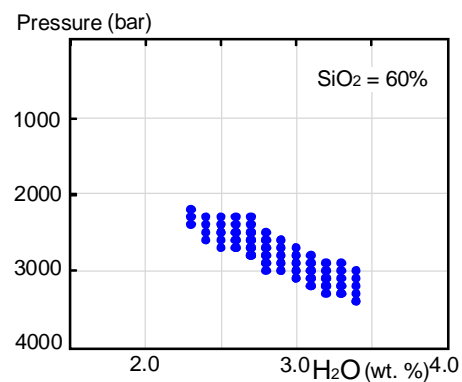

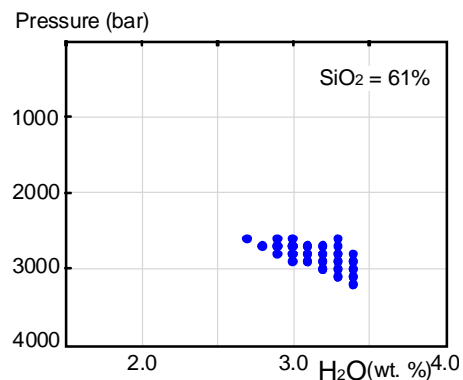

C. mafic end-member magma of upper part Pressure (bar)

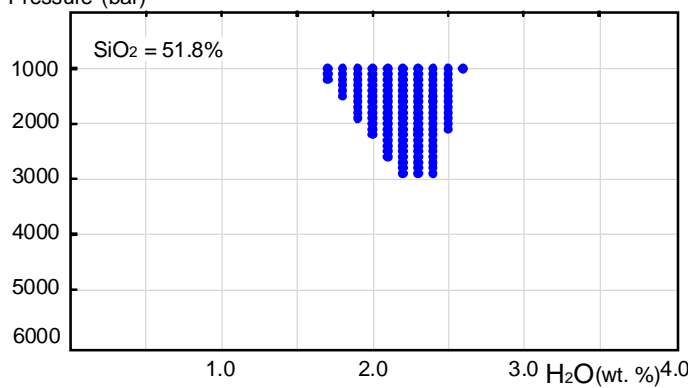

Figure 8. Graphical representation of the MELTS calculation result. At the dotted conditions, the MELTS calculation results matched the criteria (A), equilibrium precipitation of $\mathrm{An}_{62-66}$ plagioclase $+64-66 \mathrm{Mg} \#$ orthopyroxene $+66-69 \mathrm{Mg} \#$ clinopyroxene + magnetite; (B), precipitation of $\mathrm{Fo}_{83-84}$ olivine at near liquidus; (C), precipitation of high-An plagioclase $+\mathrm{Fo}_{81}$ olivine at near liquidus). In the cases of data sets of $62 \mathrm{wt} \%$ and $63 \mathrm{wt} \% \mathrm{SiO}_{2}$, no conditions within the constraints were calculated.

The Fo-poorer character of the mafic end member magma of the upper part indicates that this magma was formed from a more mafic magma through differentiation. The more mafic magma was probably the mafic end-member magma of the lower part. In addition, the reverse zoning of Fo-poorer olivine suggests the injection of the more mafic magma (mafic end-member magma of the lower part) into the differentiating magma (mafic end-member magma of the upper part).

\subsection{Formation of Mixed Magma}

The Mg-rich ( 78 in Mg\#) rims of the reversed/unzoned type orthopyroxene and the clinopyroxene phenocrysts would be formed in the initiation of the mixing between injected mafic magma and the felsic magma. The composition of the mixing magma was heterogeneous at this stage and the Mg-rich rims precipitated from a Mg-richer mixed magma. After that, the composition of the mixed magma became homogeneous and small orthopyroxene having intermediate composition (around 70 in Mg\#) (Figure 6e,f) would precipitate from the homogeneous mixed magma. The formation of the Mg-rich rims and small type orthopyroxene would be formed shortly before the eruption, because the Mg-rich rims are thin and because of the size of the small orthopyroxene.

The An-rich $\left(\mathrm{An}_{70-85}\right)$ parts of plagioclase would be formed from the Mg-richer mixed magma similar to that estimated for the Mg-rich rim of pyroxenes. The An-rich parts are observed in core, thus these were formed by the injection of mafic magma in former times before the former eruptions. Thereafter, the injected mafic magma merged into surrounding felsic magma. The discontinuous oscillation and patchy textures of the oscillatory zoned plagioclase would be formed by the heating of the injected mafic magmas. The dusty texture near the margin of the plagioclase phenocrysts was formed by the injection shortly before the eruption.

The proportions of the mafic end-member component involved in this mixing were 26-65\% for the lower part and 9-49\% for the upper part, estimated by mass balance using whole rock compositions of the mixed rock and the two end-members. 


\subsection{Basic Structure of the Magma Feeding System}

Many petrologic studies of calc-alkaline arc volcanoes have revealed that mafic magma from depths was injected into a shallower magma chamber and triggered an eruption. This is the case in the Kattadake pyroclastics. The injected mafic end-member magmas were basalts, having $49.4 \mathrm{wt} \% \mathrm{SiO}_{2}$ in lower part and $51.8 \mathrm{wt} \% \mathrm{SiO}_{2}$ in upper part, whereas the felsic end-member was andesite, having $59-61 \mathrm{wt} \% \mathrm{SiO}_{2}$ in both of the lower and upper parts. The depth of the felsic end-member magma was $\sim 6 \mathrm{~km}$ (converted from the estimated pressure condition). The mafic magma was more mafic and hotter in the lower part than in the upper part. The higher temperature mafic magma precipitated $\mathrm{Fo}_{83-84}$ olivine, while the lower temperature one precipitated high-An plagioclase $+\mathrm{Fo}_{81}$ olivine. The former mafic magma probably ascended from much deeper region of the crust. The lower temperature mafic magma would be formed by the differentiation of the hotter magma.

We estimated the crystallinity of the felsic end-member using the phenocrystic mode versus $\mathrm{SiO}_{2}$ diagram (Figure 9). The samples of lower and upper parts should plot on each linear trend between mafic and felsic end-members, because the rocks were formed by the binary mixing. $\mathrm{SiO}_{2}$ contents of the mafic end-members were estimated to be $49.5 \mathrm{wt} \%$ and $51.5 \mathrm{wt} \%$, respectively, as described above, and both of these have a few percentages of phenocrysts. In Figure 9, we drew linear trends that start at each mafic end-member and pass through each plots of lower and upper parts. The crystallinities of the felsic magmas are equivalent to the y-axis values of the trends when the $\mathrm{SiO}_{2}$ is in the range (59 to $61 \mathrm{wt} \%$ ) of the estimated felsic end-member. These are $30 \sim 36 \%$ for the lower and $46 \sim 56 \%$ for the upper part. These crystallinities indicate that the felsic chambers were in or near crystal mush condition (Marsh 1989) [25].

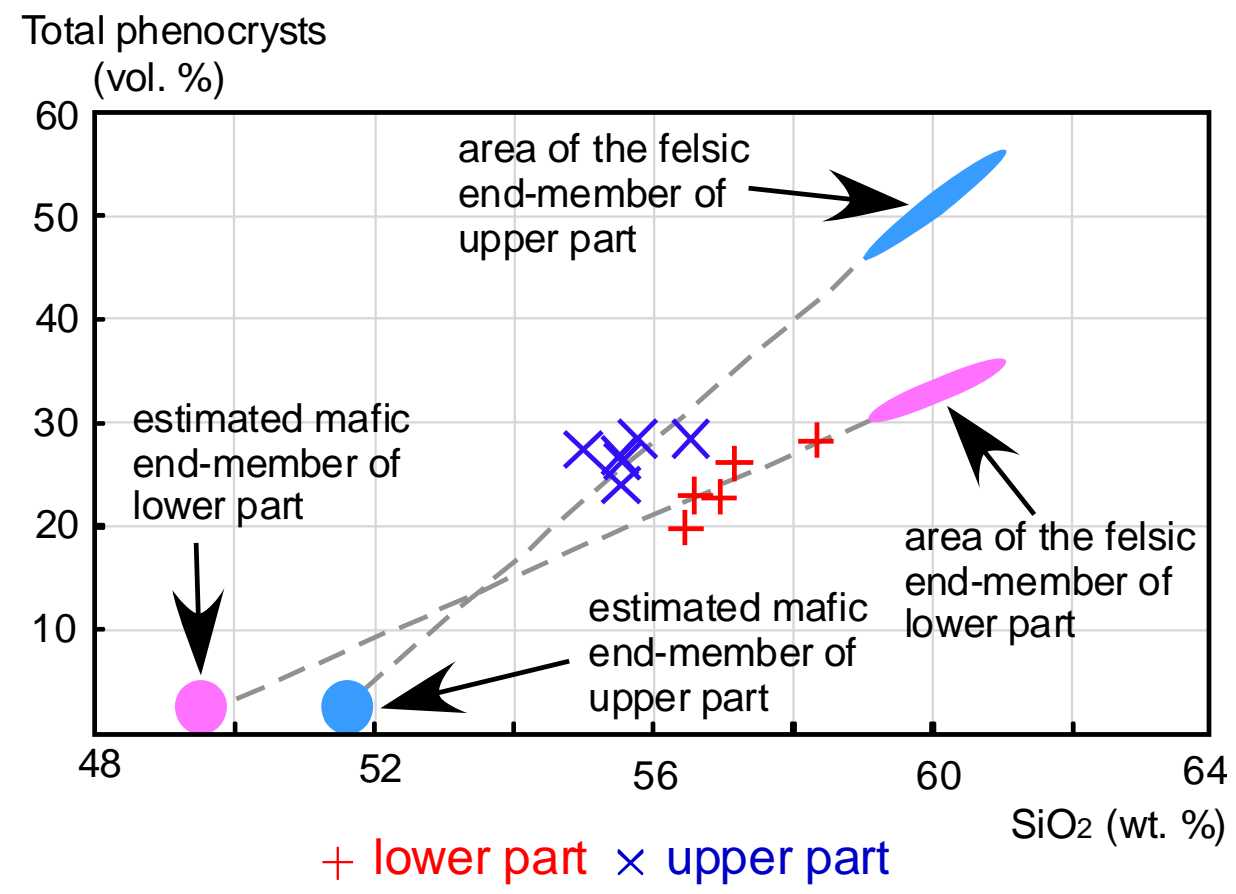

Figure 9. Phenocryst mode- $\mathrm{SiO}_{2}$ diagram of rocks from Kattadake pyroclastics.

\subsection{Reactivation of Shallow Chamber of the Kattadake Pyroclastics}

Schematic image of magma plumbing system of the Kattadake pyroclastics is presented in Figure 10. The repeated injections of the mafic magmas (having olivine with or without An-rich plagioclase) reactivated the felsic magma (having $\mathrm{Mg}$ and $\mathrm{An}$ poor pyroxenes and plagioclase) which was in or near a mush condition. 


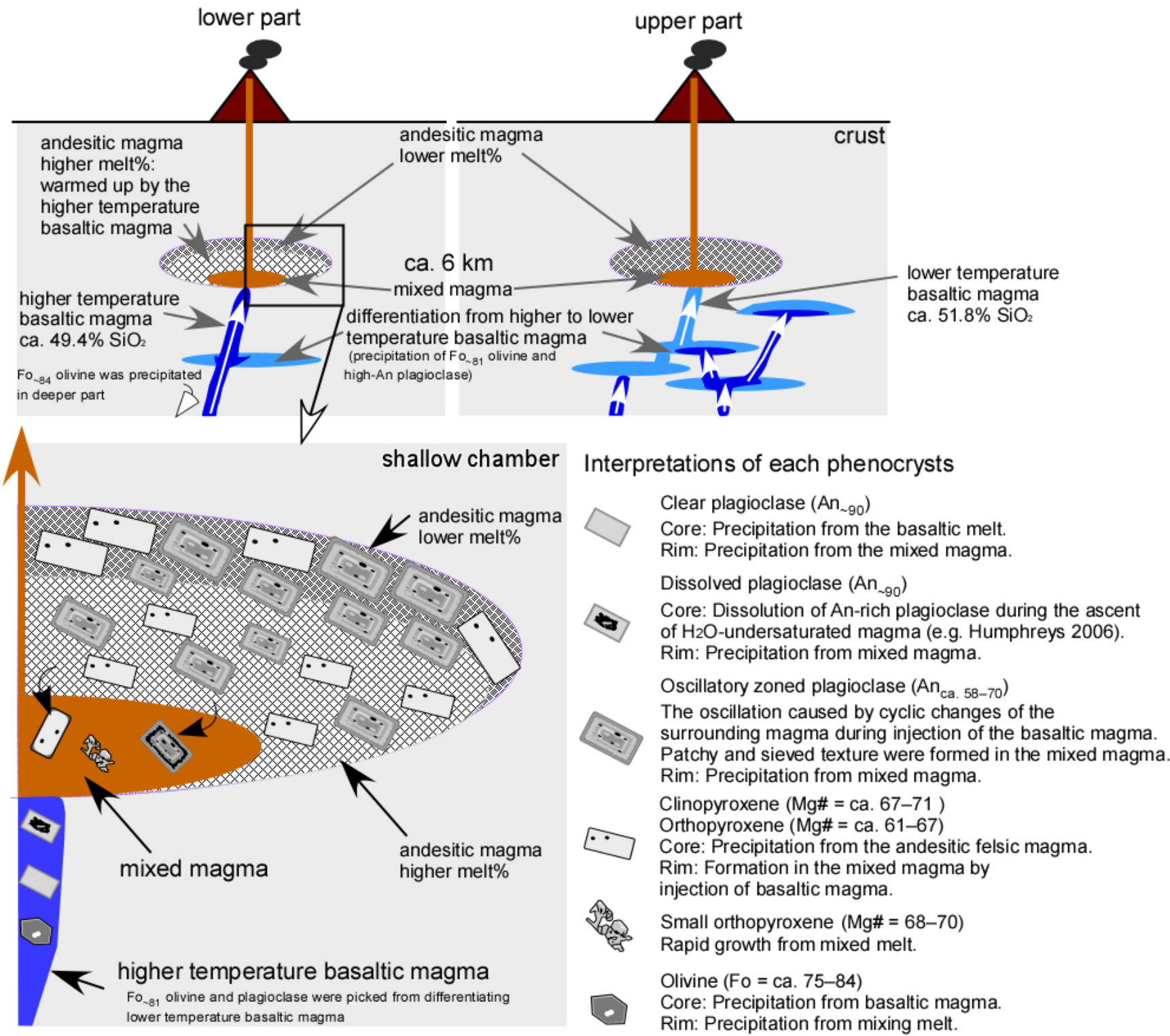

Figure 10. Schematic images of evolution of the magma plumbing system in the Kattadake pyroclastics. The interpretations of each phenocryst are also shown. See Sections 5.5 and 5.6 for further details.

The estimated temperature of mafic magma and the melt fraction $(100 \%$ minus crystallinity) of the felsic magma are higher in the lower part $\left(1170 \pm 20^{\circ} \mathrm{C}\right.$ and $\left.64-70 \%\right)$ than in upper part $\left(1100 \pm 30^{\circ} \mathrm{C}\right.$ and $\left.44-54 \%\right)$. In contrast, the mafic magma contribution in the mixed magma is lower in the lower part than in the upper part. These features can be explained as follows. The felsic magma was warmed up more efficiently before the mixing by the (higher temperature) mafic magma in the case of the lower part. Therefore, the contribution of mafic magma in forming the mixed magma was lower in lower part. In the case of upper part, the additional factors other than heating, such as forced mixing, would be more effective. In such case, therefore larger amount of the (lower temperature) mafic magma would be required to form the erupted mixed magma.

\section{Conclusions}

We investigated representative samples of lower and upper parts of the Kattadake pyroclastics of the Zao volcano (NE Japan). A petrological examination revealed the mixed nature and the compositional structure of the magma plumbing system which fed the mixed magma. 
All rocks are mixed rocks of felsic and mafic magmas. The composition of the felsic magma was common during the entire activity, whereas that of the mafic magma was more mafic in the lower part than in upper part. The felsic magma $\left(59-61 \mathrm{wt} \% \mathrm{SiO}_{2}\right.$ ) was already in a highly crystallized state and situated at ca. $6 \mathrm{~km}$ in depth. Orthopyroxene $(\mathrm{Mg \#}=61-67)$, clinopyroxene $(\mathrm{Mg} \#=67-71)$, and An-poor plagioclase $\left(\mathrm{An}_{\mathrm{ca} .58-70}\right)$ were located in this shallow chamber. The mafic magma (ca. $49.4 \mathrm{wt} \% \mathrm{SiO}_{2}$ in the lower part and ca. $51.8 \mathrm{wt} \% \mathrm{SiO}_{2}$ in the upper part) having olivine with or without plagioclase was injected into the shallow chamber. Through the injections, the mixed magmas were formed.

The estimated temperature of mafic magma is higher in the lower part than in the upper part. In accordance with this, the estimated crystallinity of the felsic magma before the mixing was lower in the lower part than in the upper part. In contrast, the mafic magma contribution was higher in the upper part than in the lower part. These relationships indicate that the hotter mafic magma in the lower part warmed up the felsic magma more effectively before mixing, which reduced the crystallinity of the felsic magma. Therefore, a smaller fraction of mafic magma was necessary to form the erupted mixed magma in the lower part.

Supplementary Materials: The following are available online at https://www.mdpi.com/article/10 $.3390 / \mathrm{min} 11040430 / \mathrm{s} 1$, Table S1: All compositions of orthopyroxene, clinopyroxene, olivine, and plagioclase the Kattadake pyroclastics.

Author Contributions: Conceptualization, M.T. and M.B.; methodology, M.T., M.B., and M.S.; software, M.T.; validation, M.T., M.B., and M.S.; formal analysis, M.T. and M.B.; investigation, M.T., M.B., M.S., and Y.N.; resources, M.T. and M.B.; data curation, M.B.; writing-original draft preparation, M.T.; writing—review and editing, M.B.; visualization, M.T.; supervision, M.B.; project administration, M.B; funding acquisition, M.B. All authors have read and agreed to the published version of the manuscript.

Funding: This study was supported by the funds from the JSPS of Japan (No. 2254087) and ERI JURP (2009-A-13).

Data Availability Statement: All data presented in this study are included in this article and electronically supplemental file.

Acknowledgments: We highly appreciate the constructive reviews of anonymous reviewers and helpful comments of the academic editor, Pier Paolo Giacomoni. We are grateful to the Miyagi and Yamagata Prefecture Governments to have given us special permissions to collect samples in the protected area of Zao volcano.

Conflicts of Interest: The authors declare that they have no known competing financial interests or personal relationships that could have appeared to influence the work reported in this paper.

\section{References}

1. Manrique, N.; Samaniego, P.; Médard, E.; Schiavi, F.; Mariño, J.; Liorzou, C. Pre-eruptive magmatic processes associated with the historical (218 $\pm 14 \mathrm{aBP})$ explosive eruption of Tutupaca volcano (southern Peru). Bull. Volcanol. 2019, 82, 6. [CrossRef]

2. Hodge, K.F.; Jellinek, A.M. The Influence of Magma Mixing on the Composition of Andesite Magmas and Silicic Eruption Style. Geophys. Res. Lett. 2020, 47, 13. [CrossRef]

3. Murphy, M.D.; Sparks, R.S.J.; Barclay, J.; Carroll, M.R.; Brewer, T.S. Remobilization of andesiticmagma by intrusion of maficmagma at the Soufriere Hills volcano, Montserrat, West Indies. J. Petrol. 2000, 41, 21-42. [CrossRef]

4. Plail, M.; Edmonds, M.; Woods, A.W.; Barclay, J.; Humphreys, M.C.S.; Herd, R.A.; Christopher, T. Mafic enclaves record syn-eruptive basalt intrusion and mixing. Earth Planet. Sci. Lett. 2018, 484, 30-40. [CrossRef]

5. Izbekov, P.E.; Eichelberger, J.C.; Ivanov, B.V. The 1996 eruption of Karymsky volcano, Kamchatka: Historical record of basaltic replenishment of an andesite reservoir. J. Petrol. 2004, 45, 2325-2345. [CrossRef]

6. Patia, H.; Eggins, S.M.; Arculus, R.J.; McKee, C.O.; Johnson, R.W.; Bradney, A. The 1994-2001 eruptive period at Rabaul, Papua New Guinea: Petrological and geochemical evidence for basalt injections into a shallow dacite magma reservoir, and significant SO2 flux. J. Volcanol. Geotherm. Res. 2017, 345, 200-217. [CrossRef]

7. Eichelberger, J.C. Vesiculation of mafic magma during replenishment of silicic magma reservoirs. Nature 1980, 5790, 446-450. [CrossRef]

8. Snyder, D. Thermal effects of the intrusion of basaltic magma into a more silicic magma chamber and implications for eruption triggering. Earth Planet. Sci. Lett. 2000, 175, 257-273. [CrossRef] 
9. Cooper, K.M. Time scales and temperatures of crystal storage in magma reservoirs: Implications for magma reservoir dynamics. Philos. Trans. R. Soc. A 2019, 377, 20180009. [CrossRef]

10. Nishi, Y.; Ban, M.; Takebe, M.; Álvarez-Valero, A.M.; Oikawa, T.; Yamasaki, S. Structure of the shallow magma chamber of the active volcano Mt. Zao, NE Japan: Implications for its eruptive time scales. J. Volcanol. Geotherm. Res. 2019, 371, 137-161. [CrossRef]

11. Singer, B.S.; Costa, F.; Herrin, J.S.; Hildreth, W.; Firestein, J. The timing of compositionally-zoned magma reservoirs and mafic 'priming' weeks before the 1912 Novarupta-Katmai rhyolite eruption. Earth Planet. Sci. Lett. 2016, 451, 125-137. [CrossRef]

12. Morgado, E.; Morgan, D.J.; Castruccio, A.; Ebmeier, S.K.; Parada, M.; Brahm, R.; Harvey, J.; Gutiérrez, F.; Walshaw, R. Old magma and a new, intrusive trigger: Using diffusion chronometry to understand the rapid-onset Calbuco eruption, April 2015 (Southern Chile). Contrib. Mineral. Petrol. 2019, 174, 61. [CrossRef]

13. Yamamoto, M.; Miura, S.; Ichiki, M.; Hirahara, S. Shallow long-period seismic events at Zao volcano. In Proceedings of the Abstract Annual Meeting Bull. Volcanological Society Japan, A3-13, Fukuoka, Japan, 2-4 November 2014. (In Japanese).

14. Ban, M.; Oikawa, T.; Yamasaki, S.; Goto, A.; Yamamoto, M.; Miura, S. Prediction of Eruption Courses in Volcanoes Without Eruptions Under Modern Observation System: Example of Zao Volcano. Bull. Volcanol. Soc. Jpn. 2019, 64, 131-138, (In Japanese with English abstract).

15. Miura, S.; Yamamoto, M.; Demachi, T.; Ichiki, M. Volcanic deformation around Mt. Zao. In Proceedings of the Abstract Annual Meeting Bull. Volcanological Society Japan, A2-05, Akita, Japan, 26-28 September 2018. (In Japanese)

16. Ban, M.; Oikawa, N.; Yamazaki, S. Geological Map of Zao Volcano; Geological Survey of Japan, AIST: Tsukuba, Japan, 2015.

17. Yamada, Y.; Kohno, H.; Murata, M. A low dilution fusion method for major and trace element analysis of geological samples. Advan. X-ray Anal. 1995, 26, 33-44, (In Japanese with English abstract)

18. Murata, M. Major and trace elements analysis of Korea Institute of Energy and Resources igneous rock reference samples using X-ray fluorescence spectrometer. J. Naruto. Coll. Educ. 1993, 8, 37-50.

19. Gill, J.B. Orogenic Andesites and Plate Tectonics; Springer: Berlin/Heidelberg, Germany; New York, NY, USA, 1981 ; pp. 1-392.

20. Miyashiro, A. Volcanic rock series in island arcs and active continental margins. Am. J. Sci. 1974, 274, 321-355. [CrossRef]

21. Viccaro, M.; Giacomoni, P.P.; Ferlito, C.; Cristofolini, R. Dynamics of magma supply at Mt. Etna volcano (Southern Italy) as revealed by textural and compositional features of plagioclase phenocrysts. Lithos 2010, 116, 77-91. [CrossRef]

22. Tsuchiyama, A. Dissolution kinetics of plagioclase in the melt of the system diopside-albite-anorthite, and origin of dusty plagioclase in andesites. Contrib. Mineral. Petrol. 1985, 89, 1-16. [CrossRef]

23. Andújar, J.; Scaillet, B.; Pichavant, M.; Druitt, T.H. Generation Conditions of Dacite and Rhyodacite via the Crystallization of an Andesitic Magma. Implications for the Plumbing System at Santorini (Greece) and the Origin of Tholeiitic or Calc-alkaline Differentiation Trends in Arc Magmas. J. Petrol. 2016, 57, 1887-1920. [CrossRef]

24. Hildreth, W. Volcanological perspectives on Long Valley, Mammoth Mountain, and Mono Craters: Several contiguous but discrete systems. J. Volcanol. Geotherm. Res. 2004, 136, 169-198. [CrossRef]

25. Marsh, B.D. Magma chambers. Ann. Rev. Earth Planet. Sci. 1989, 17, 439-474. [CrossRef]

26. Matsui, Y.; Nishizawa, O. Iron (II)-magnesium exchange equilibrium between olivine and calcium-free pyroxene over a temperature range $800{ }^{\circ} \mathrm{C}$ to $1300{ }^{\circ} \mathrm{C}$. Bull. Soc. Fr. Mineral. Cristallogr. 1974, 97, 122-130.

27. Obata, M.; Banno, S.; Mori, T. The iron-magnesium partitioning between naturally occurring coexisting olivine and Ca-rich clinopyroxene: An application of the sample mixture model to olivine solid solution. Bull. Soc. Fr. Mineral. Cristallogr. 1974, 97, 101-107.

28. Humphreys, M.C.S.; Blundy, J.D.; Sparks, R.S.J. Magma evolution and open-system processes at Shiveluch volcano: Insights from phenocryst zoning. J. Petrol. 2006, 47, 2303-2334. [CrossRef]

29. Gualda, G.A.R.; Ghiorso, M.S.; Lemons, R.V.; Carley, T.L. Rhyolite-MELTS: A modified calibration of MELTS optimized for silica-rich, fluid-bearing magmatic systems. J. Petrol. 2012, 53, 875-890. [CrossRef]

30. Sack, R.O.; Carmichael, I.S.E.; Rivers, M.; Ghiorso, M.S. Ferric-ferrous equilibria in nature silicate liquids at 1 bar. Contrib. Mineral. Petrol. 1980, 75, 369-376. [CrossRef]

31. Ban, M.; Sagawa, H.; Miura, K.; Hirotani, S. Evidence for a short lived stratified magma chamber: Petrology of the Z-To 5 tephra layer (c. $5.8 \mathrm{ka}$ ) at Zao volcano, NE Japan. In Dynamics of Crustal Magma Transfer, Storage and Differentiation; Annen, C., Zellmer, G.F., Eds.; Geological Society: London, UK, 2008; Volume 304, pp. 149-168.

32. Brey, G.; Köhler, T. Geothermobarometry in four-phase lherzolites II. New thermobarometers, and practical assessment of existing thermobarometers. J. Petrol. 1990, 31, 1353-1378. [CrossRef]

33. Sisson, T.W.; Grove, T.L. Experimental investigations of the role of $\mathrm{H}_{2} \mathrm{O}$ in calc- alkaline differentiation and subduction zone magmatism. Contrib. Mineral. Petrol. 1993, 113, 143-166. [CrossRef] 